\title{
Activity of chars and activated carbons for removal and decomposition of tar model compounds - A review
}

Ravenni, Giulia; Sárossy, Zsuzsa ; Ahrenfeldt, Jesper; Henriksen, Ulrik Birk

\section{Published in:}

Renewable and Sustainable Energy Reviews

Link to article, DOI:

10.1016/j.rser.2018.07.001

Publication date:

2018

Document Version

Peer reviewed version

Link back to DTU Orbit

Citation (APA):

Ravenni, G., Sárossy, Z., Ahrenfeldt, J., \& Henriksen, U. B. (2018). Activity of chars and activated carbons for removal and decomposition of tar model compounds - A review. Renewable and Sustainable Energy Reviews, 94, 1044-1056. https://doi.org/10.1016/j.rser.2018.07.001

\section{General rights}

Copyright and moral rights for the publications made accessible in the public portal are retained by the authors and/or other copyright owners and it is a condition of accessing publications that users recognise and abide by the legal requirements associated with these rights.

- Users may download and print one copy of any publication from the public portal for the purpose of private study or research.

- You may not further distribute the material or use it for any profit-making activity or commercial gain

- You may freely distribute the URL identifying the publication in the public portal 
1

\author{
Activity of chars and activated carbons for removal and decomposition of tar model compounds - A \\ review \\ Giulia Ravenni, Zsuzsa Sárossy, Jesper Ahrenfeldt, Ulrik Birk Henriksen \\ Technical University of Denmark (DTU), Department of Chemical and Biochemical Engineering \\ Frederiksborgvej 399, 4000 Roskilde, Denmark \\ Corresponding author: Giulia Ravenni Phone: +45 93511592 E-mail: grav@kt.dtu.dk
}

\begin{abstract}
Chars, or carbonized products produced by pyrolysis or gasification, have a porous structure, a high specific surface area and they can be rich in micropores. Such characteristics make them suitable to be used in the cleaning of gasification producer gas. Several authors have been investigating the mechanism of the interaction between tar compounds and char, in order to understand the potential of this application. This review is aimed at summarizing results from reported experimental campaigns, carried out to study the effect of char beds on tar compounds: several research groups have been investigating the subject over the years, using different experimental methods and different chars or activated carbon (AC).

After a first section dedicated to the definition of char and tars, this work reviews a series of studies where model compounds were used to predict the behavior of real tars upon contact with char surface. The review includes research works focused on alkanes decomposition (methane, propane) and more traditional aromatic model tars. The overview of the results shows that the use of biomass char is effective in converting up to $100 \%$ of model tars in a gaseous stream, with coke, $\mathrm{H}_{2}$, and $\mathrm{CO}$ and $\mathrm{CO}_{2}$ as major products of cracking and reforming reactions. In particular, multi-ring aromatics such as naphthalene showed higher conversion rates. Tar conversion at $700-900^{\circ} \mathrm{C}$ is favored by the presence of reforming agents $\left(\mathrm{H}_{2} \mathrm{O}, \mathrm{CO}_{2}\right)$, which also contribute in preserving the activity of char over time. Residual char properties that enhance the activity toward tar decomposition include a large surface area and a well-developed microporosity. Both the char properties and the process parameters need to be carefully optimized for the successful application of residual gasification char to producer gas cleaning, and further experiments on real producer gas are needed to implement char-based gas cleaning systems.
\end{abstract}

Keywords: gasification, biomass, char, active carbon, model tar, gas cleaning 


\section{Introduction}

In recent years, the increased $\mathrm{CO}_{2}$ emissions and the related global climatic issues have encouraged research about alternative energy sources to replace fossil fuels. Biomass does not contain fossil carbon, and therefore it has the potential to be a source of renewable energy. Particularly, one of the most promising technologies for biomass-to-energy conversion is gasification. The producer gas can be used for several applications: it can fuel gas turbines or reciprocating engines, or it can be used to produce methane, methanol or Fischer-Tropsch fuels. Gasification has the major drawback of requiring extensive gas cleaning, and the most problematic substance in producer gas is considered to be tar. Tar compounds are generally high molecular weight hydrocarbons that can easily condense, causing several operational problems in downstream processes and components. They are formed during pyrolysis and evolve during gasification in a series of complex reactions: their nature is strongly dependent on the process conditions.

Many methods for removing tars from producer gas have been investigated, and they can be divided into two main groups: primary and secondary methods [1]. Primary methods act inside the gasifier (in-situ) to prevent tar formation or convert nascent tars, e.g. modification of the gasifier design or optimization of operating conditions, and addition of bed additives or catalysts. Common bed additives are Ni-based catalysts, dolomites and magnesites, zeolites, olivine and iron catalysts: they are effective in reducing the amount of tars, by converting them into stable gases $\left(\mathrm{H}_{2}, \mathrm{CO}\right.$ and $\left.\mathrm{CO}_{2}\right)$, but they encounter deactivation and cause problems related with the carryover of fines [1]. Secondary methods include various downstream treatments such as hot gas cleaning (thermal or catalytic cracking, oxidative and steam conversion), and mechanical methods such as cyclones and filters. In general, thermal and catalytic methods are considered the most attractive because of their high effectivity. However, they require careful optimization in order to minimize the energy consumption and preserve the overall efficiency of the process. At present, none of these methods has been found to be a breakthrough, in terms of effectivity and economic viability.

A potential solution for downstream tar removal is the use of char. Ideally, after gasification the feedstock is reduced to pure ash, but usually the more stable fraction of carbon is preserved in the residues of the process, especially in gasifiers operating at low temperature $\left(750-800^{\circ} \mathrm{C}\right)$ [2]. Being a by-product of gasification, char is continuously produced and available. If used for gas cleaning it could avoid the problem of deactivation, which is usually limiting for other catalysts: spent char can be continuously recycled in the system and gasified along with fresh feedstock. In addition, residual char is currently considered a waste for disposal, therefore its repurposing would represent an economic benefit for any gasification plant [3].

Understanding and optimizing the interaction between char and tars is not an easy task and it requires bringing together carbon science and tar chemistry. Depending on the composition of the tar mixture, char properties and reaction conditions, different physical and chemical processes can take place on char surface when contacting 
with tars. The complexity of the problem is given by the heterogeneity of the tar mixture and by the nature of char, which can have manifold characteristics depending on the conditions of carbonization. In order to simplify the matter, model compounds are often used in laboratory-scale experiments to predict the behavior of the real tar mixture. Several research groups have used single tar compounds for investigating reaction paths and quantify the conversion of certain aromatics or alkanes. Adsorption capacity and catalytic activity for model tars conversion were measured for different carbon materials, and often commercial activated carbon was chosen as reference. In some cases, char was impregnated with metal oxides or alkali, or acid washed to remove all inorganics with the aim of investigating separately the effect of different char characteristics.

This work collects results from a series of studies dedicated to tar model compounds interacting with a solid carbon surface. The need for organizing such results is given by the lack of a method for establishing the efficiency of char for tar conversion, and the lack of a systematic evaluation of the main parameters influencing the efficiency of char for tar conversion (char properties and reaction conditions). Researchers have been using a variety of different setups, reaction conditions and char types in the experiments. The aim of this review is to identify the main reaction pathways and to list the most important parameters affecting tar decomposition on the char surface. Such overview provides basis for a more rigorous definition of the interaction mechanisms between tar compounds and solid carbon, paving the way to the design of tar removal systems based on char.

The first section of this review is dedicated to clarifying the terminology to define char and similar carbonaceous materials. Next, the most commonly used model tar compounds are shortly presented. The following section is dedicated to the effect of char on alkanes, while the last focuses on mono-ring aromatics and Polycyclic Aromatic Hydrocarbons (PAHs).

\section{Defining carbon materials for gas cleaning applications}

Carbon can be found in nature with different shapes and structures: diamond, graphite, graphene, or less ordered forms such as char or activated carbon. To avoid disarray, it is useful to clarify the terminology used for the different carbon materials treated in this review, referring to the definitions given by the International Committee for Characterization and terminology of Carbon [4,5].

\subsection{Carbonization}

The carbonaceous materials treated in this work are the solid products of carbonization, a process which is defined as "the formation of material with increasing carbon content from organic material, usually by pyrolysis" [4]. Carbonization can take place under different conditions (pressure, temperature, oxygen level), thus producing different carbonaceous structures. The process leads to a progressive increase in the crystalline order: during pyrolysis, volatiles are removed from the organic material, and the carbon atoms are arranged in stacks of flat aromatic sheets randomly cross-linked [6]. The sequence of structural changes occurring during 
biomass carbonization is well described by Keiluweit et al.[7]. At temperatures higher than $700^{\circ} \mathrm{C}$, turbostratic carbon (Figure 1a) is formed: it is still less packed and less ordered in comparison with graphite-like carbon (Figure 1b), therefore it results in higher porosity and high surface area [8]. High carbonization temperatures $\left(1000^{\circ} \mathrm{C}\right)$ decrease the total porosity because of the formation of graphite with a more closely packed structure [9].

In presence of a limited amount of oxidizing agent (sub-stoichiometric), partial combustion leads to an increase in temperature and char is exposed to the endothermic gasification reactions: some of the carbon will react leaving the residual char structure with a more stable carbon fraction, fewer functional groups and a larger ash fraction.

\subsection{Char and activated carbon}

Two types of carbonization products are of particular interest in this context: char and activated carbon (AC). As defined by the International Committee, char is "a carbonization product of a natural or synthetic organic material, which has not passed through a fluid stage during carbonization" [5]. The parent material for char can be coal or biomass.

Biochar is a particular type of char which is mainly intended for soil application, and should meet specific criteria as described in the European Biochar Certificate (EBC) [11] or the International Biochar Initiative (IBI) Standard [12]. Both are voluntary standards and describe biochar as a material produced through oxygen-limited thermal conversion of biomass, thus including pyrolysis and gasification processes.

On the other hand, AC is " a char, which has been subjected to reaction with gases, sometimes adding chemicals, e.g. $\mathrm{ZnCl}_{2}$, during or after carbonization in order to increase its porosity" [5]. During activation, the irregular structure of char reacts with gases, enhancing the porosity of the material. This gives the ACs a large surface area (up to $2500 \mathrm{~m}^{2} / \mathrm{g}$ ), a microporous structure and a high surface reactivity [13]. The structure of activated carbons has been described by Stoeckli [14] as constituted by bent aromatic sheets and strips with gaps of various dimension between them, forming slit-shaped micropores (Figure 2).

ACs are widely used in adsorption processes. They may assist the capture of organic volatile compounds and adsorb hydrocarbons and PAHs [15-22]. ACs are also commonly used for gas cleaning in combustion plants, to remove metals and dioxins at $150-200^{\circ} \mathrm{C}[23]$.

The structural characteristics of carbon materials are defined by the distribution of micropores (cavities with mouths smaller than $2 \mathrm{~nm}$ ), mesopores and macropores $(>50 \mathrm{~nm})$, while the chemical properties are defined by the inorganics dispersed on the surface and by the presence of oxygen-containing functional groups at the edges of the graphite sheets: acidic groups such as lactones, carboxylic acid or phenol and basic groups such as 
carbonylic, quinonic and pyrone structures. Oxygen sites enhance the adsorption of polar molecules and in general they are known to influence the adsorption capacity and catalytic activity of char $[6,18,24]$.

Biomass-derived char generally has a lower surface area and adsorption capacity in comparison with ACs, but nonetheless shares many of their features. This is particularly true if char undergoes a certain degree of gasification, which is analogue to an activation process. Even if it does not undergo activation, char usually has a porous structure, a high surface area and it is rich in micropores.

The parent material naturally contains minor elements such as Alkali and Alkaline Earth Metals (AAEM), Fe, $\mathrm{Al}, \mathrm{Si}$ and $\mathrm{P}$ that can increase the catalytic properties [25]. Moreover, depending on the carbonization conditions, the surface of char can have oxygen functional groups.

Because of its AC-like characteristics, char has a good potential to be used as adsorbent, catalyst support, and even as a catalyst on its own [6,25-28]. Specifically, it offers a number of favorable features for adsorption and catalytic conversion of aromatics and alkanes. In recent years, the application of non-activated carbonization products to gas treatment has been suggested and studied by several authors. A study by Benedetti et al.[3], considers gasification-derived biochar as a substitute for AC, pointing out that double-stage gasifiers are particularly suitable for producing residual char with characteristics comparable with AC. As a matter of fact, in staged processes the pyrolysis and the gasification steps are carried out separately, thus resembling an AC manufacturing process. Residual char has therefore the potential to be used as AC without any further activation treatment: operating conditions of gasification can be tuned to deliver a residual char with suitable properties to be directly used for adsorption or gas treatment.

\section{Tar model compounds}

A general classification of the compounds in the tar mixture is based on their order of appearance within the gasification process [29]:

- Primary tars are produced during pyrolysis, in the temperature range $400-700^{\circ} \mathrm{C}$. They are completely converted if the temperature surpasses $800^{\circ} \mathrm{C}$. This class includes oxygenated compounds such as levoglucosan, hydroxyacetaldehyde and furfurals originating from cellulose and hemicellulose, together with methoxyphenols which are derived from lignin.

- Secondary tars are formed by gas-phase reactions of primary tars at $700-850^{\circ} \mathrm{C}$ and they include phenolic compounds and alkenes (Table 1). The abundance of this class of tars has a peak around $750^{\circ} \mathrm{C}$

- Tertiary tars include methyl-derivatives of aromatics, such as methyl-acenaphthylene, methylnaphthalene, toluene and indene. They are formed in the temperature range 650 to $1000^{\circ} \mathrm{C}$. Polycyclic Aromatic 
To investigate and predict the behavior of tars, model compounds have been widely used as representatives of different tar classes. Some of the most common model tar molecules are reported in Table 1. Toluene, phenol and naphthalene are frequently used, as these compounds generally make up the most part of total tar. PAHs are also often used as model tars because they are problematic pollutants in the producer gas, and they are highly refractory. In some cases, alkanes such as methane and propane have been used as model tars, even if they lack the aromatic structure or not defined as members of the above tar classes.

Indeed, there may be differences in the behavior of model tars in comparison with real tar mixtures, and results should always be treated considering the differences with actual process conditions. It is here appropriate to consider the works published by Mastral and colleagues, where the adsorption of pure model PAHs on ACs was compared with the behavior of PAHs mixtures [30], PAHs with steam [31], and PAHs-containing flue gases from real combustion [9]. The differences in the adsorption dynamics showed that the process is affected by the presence of molecules different from the pure model compounds. Specifically, a mixture of naphthalene and phenanthrene was adsorbed on AC, and it was observed that the presence of a second PAH in the gas stream reduced the adsorption efficiency, as both molecules compete for adsorption sites [30]. Similarly, adsorption tests of various PAHs in presence of combustion flue gas revealed that other molecules $\left(\mathrm{H}_{2} \mathrm{O}\right.$, smaller volatile organic compounds) can compete with PAHs, blocking the narrowest adsorption sites and affecting the overall adsorption capacity [9]. Indeed, the presence of steam in the gas phase (10\%) decreased the adsorption capacity of phenanthrene for 13 out of 16 tested ACs [31].

This suggests that results obtained by using model compounds alone should be verified in conditions as similar as possible to reality. Nonetheless, studying the behavior of model compounds can be useful in understanding the adsorption or decomposition dynamic of real tars.

\section{High temperature chemistry of alkanes as tar model compounds over char}

Studies on heterogeneous reactions of light hydrocarbons have been investigated in order to understand the catalytic properties of a carbonaceous surface within the temperature range $850-1000^{\circ} \mathrm{C}$. An overview of the experimental conditions in the reviewed papers can be found in Table 2. It is worthwhile to include this section in the present review, as many of the processes observed at the surface of char or AC are similar to those encountered for aromatic model tars. Particularly, the decomposition of methane through carbon deposition, often referred to as thermocatalytic decomposition (Reaction 1), has been object of study because carbon materials offer advantages to be used as catalyst for $\mathrm{H}_{2}$ production [32]. 


\section{Reaction 1}

Muradov [32] tested different types of commercial AC as catalysts for this application: ACs exhibited high initial catalytic activity, but showed deactivation over 1-hour period. A proportional relationship was observed between the catalytic activity and the BET specific surface area of AC. The same author [33] worked also with various carbon materials (AC, carbon black, graphite, glassy carbon, acetylene black), with the aim to determine the structural or chemical factors influencing $\mathrm{CH}_{4}$ decomposition. The "degree of order" in the carbon structure was found to affect heterogeneous reactions: amorphous or microcrystalline carbons such as ACs appear to be richer in energetic discontinuities (e.g. reactive edges of carbon crystallites), forming active sites for $\mathrm{CH}_{4}$ decomposition. Furthermore, these results showed that transition metals impurities on the carbon surface play a minor role in catalysis. Oxygen-containing functional groups appeared to have an effect solely in the first stages of the process.

Likewise, Moliner et al.[34] compared the activity of various ACs for $\mathrm{CH}_{4}$ decomposition. They focused on the effect of surface chemistry and porosity and concluded that the most effective chars were the ones with a BET surface area around $1000 \mathrm{~m}^{2} / \mathrm{g}$. The concentration of oxygen functional groups on the surface only influenced the initial activity, but did not correlate with longer-term activity of chars, in agreement with [33]. Deactivation was observed and ascribed to micropores blocking by carbon deposition. Prolonged activity (240 min) was ensured by large surface area, together with an appropriate pore size distribution including mesopores and wide microporosity to facilitate diffusion. Suelves et al.[35] further evaluated the effect of different textural characteristics of $\mathrm{AC}$ on $\mathrm{CH}_{4}$ conversion by using thermogravimetric analysis (TGA) to quantify the deposition of solid carbon. The results showed that the higher the total pore volume of fresh char, the higher the amount of deposited carbon, meaning that a larger pore volume implies an increased activity. They also confirmed the relation between the concentration of oxygenated functional groups and the initial reaction rate.

Dufour et al.[36] evaluated the catalytic activity of wood char (non-activated) for $\mathrm{CH}_{4}$ decomposition investigating the role of inorganics $(\mathrm{K}, \mathrm{Ca}$ and $\mathrm{Mg}$ ), pore texture and surface chemistry. Since demineralized samples exerted the same methane conversion as untreated ones, the authors surmise that the effect of inorganics is negligible. Similar remarks were made for the role of oxygen surface groups. As a consequence, active sites for carbon deposition are rather likely to be constituted by unsaturated carbon atoms, forming high energy sites as described also in [33]. $\mathrm{CH}_{4}$ reacting in a $\mathrm{N}_{2}$ atmosphere rapidly deactivated the carbon catalyst, probably because of the pores closure due to carbon deposition. In agreement with results from other studies ([37-39]), the presence of $\mathrm{CO}_{2}$ or $\mathrm{H}_{2} \mathrm{O}$ was found to prevent the pores blocking and to maintain the char catalytic activity. In a latter work, Dufour et al.[40] examined more closely the mechanism of deactivation and regeneration of wood char, confirming the role of steam gasification for the long-term sustainability of $\mathrm{H}_{2}$ production. During $\mathrm{CH}_{4}$ conversion, a thin coating of reactive pyrolytic carbon was formed on the surface. The authors suggest that 
wood char might represent a cheap and effective catalyst for converting both $\mathrm{CH}_{4}$ and tars into an $\mathrm{H}_{2}-$ rich syngas.

The catalytic properties of gasification-derived char for the decomposition of $\mathrm{CH}_{4}$ and $\mathrm{C}_{3} \mathrm{H}_{8}$ were investigated by Klinghoffer et al.[41]. The properties of wood char produced in a fluid bed gasifier under different conditions (steam, $\mathrm{CO}_{2}, 550,750$ and $920^{\circ} \mathrm{C}$ ) were investigated alongside with the char activity toward alkanes decomposition. Results showed that char surface area and the micropore structure strongly depends on the gasification conditions: longer residence time and higher temperature favored the development of a large surface area. The use of $\mathrm{CO}_{2}$ as a gasifying agent, in comparison with steam, enhanced the formation of micropores. Char catalytic activity on the decomposition of $\mathrm{CH}_{4}$ and $\mathrm{C}_{3} \mathrm{H}_{8}$, was measured by TGA. The mass gain of char was used to quantify the deposition on the surface from hydrocarbon decomposition. Exposure to $\mathrm{CH}_{4}$ induced an increase of the char mass starting at $700^{\circ} \mathrm{C}$. At the same temperature, $\mathrm{C}_{3} \mathrm{H}_{8}$ induced a higher mass gain. According to the author, these results demonstrate the ability of char to catalyze hydrocarbon decomposition via cleavage of $\mathrm{C}-\mathrm{C}$ and $\mathrm{C}-\mathrm{H}$ bonds, suggesting that char may be a good catalyst for tar decomposition. Post-test characterization of char surface in Environmental Scanning Microscopy and Energy Dispersive X-ray (ESEM/EDX) showed a high carbon concentration on the pores, especially at the iron sites, suggesting that the metal acts as an active site for catalytic reactions.

The same research group [25] further studied the role of inorganics at the char surface and oxygen functional groups as well. The effect of acidic oxygen groups was tested on $\mathrm{CH}_{4}$ decomposition at $850^{\circ} \mathrm{C}$ and was found not to play an important role: this is ascribed to the fact that acidic oxygen groups are desorbed from the char surface at temperatures lower than $850^{\circ} \mathrm{C}$.

Inorganics such as $\mathrm{Ca}, \mathrm{Na}, \mathrm{K}, \mathrm{Mg}, \mathrm{P}, \mathrm{Si}, \mathrm{Fe}, \mathrm{Al}$ and $\mathrm{Mn}$ were present in the char and in general higher concentrations lead to a higher catalytic activity. Furthermore, the activity of char was higher than that of pure ashes, indicating that carbon works as support on which inorganics are dispersed. Indeed, the author refers to gasification char as a "supported metal catalyst" [41] where the carbonaceous structure with a high surface area provides support for the ash elements.

These studies highlight the most important characteristics of a carbon material such as char for its activity in acyclic hydrocarbons decomposition. Textural characteristics such as large surface area and pore volume are considered essential to the activity of char, especially for the longevity of its catalytic effect. The role of inorganic impurities is not yet defined: to some extent, transition metals such as $\mathrm{Ni}$ and $\mathrm{Fe}$ and AAEMs were found to play a role in $\mathrm{CH}_{4}$ decomposition. Certainly the presence of heteroatoms in the carbon structure, together with a low degree of crystalline order promoted the abundance of active sites. In general, results obtained on the decomposition of alkanes showed some promising characteristics of AC, as well as nonactivated biomass char for the decomposition of hydrocarbons. 


\section{Adsorption and high temperature chemistry of aromatics as tar model compounds over char}

Aromatics are usually the main components of the tar mixture, and they are highly refractory as a consequence of their molecular structure. Their stability is given by the delocalization of electrons in the $\pi$-bonds between carbon atoms in the cyclic structure. This effect increases with the number of conjugated rings, making larger PAHs more difficult to remove by thermal treatment. Such process leaves the aromatic structure unchanged. The range of temperatures where physical adsorption is applied is in generally below $250^{\circ} \mathrm{C}$ because, as temperature is increased, the adsorption capacity is reduced as a result of the exothermic nature of adsorption processes [42]. On the other hand, at higher temperatures chemical bonding with the surface (chemisorption) can take place. Chemisorption is characterized by large interaction potentials: it is often found to occur at temperatures higher than the critical temperature of the adsorbate [43] (e.g. $748.4^{\circ} \mathrm{C}$ for naphthalene, $869^{\circ} \mathrm{C}$ for phenanthrene [44]). If aromatics are chemisorbed, their molecular structure is modified, and this can be the first stage of a catalytic process leading to cracking and reforming of heavy aromatics. In the following, a series of papers are reviewed were physisorption or chemisorption were studied. An overview of all the experimental conditions is given in Table 3 and Table 4.

The conversion of model tars is commonly expressed as $\mathrm{X}$ (Equation 1)

$X=\frac{C_{\text {in }}-C_{\text {out }}}{C_{\text {in }}} * 100[\%]$

(Equation 1)

Being $\mathrm{C}_{\mathrm{in}}$ and $\mathrm{C}_{\mathrm{out}}$ the model tar concentrations at the inlet and outlet, respectively.

\subsection{Physical adsorption}

Physical adsorption plays an important role in the interaction between hydrocarbons and the surface of chars, therefore it is useful to understand what parameters control this process. ACs are popular for adsorption of PAHs from aqueous solutions [45]. Such a process has been object of several studies, and some of them also investigated the use of biochars for this application [46,47]. In particular, Li et al.[46] found the adsorption capacity of biochars for phenanthrene, fluorene and pyrene to increase with the carbonization temperature (600 to $800^{\circ} \mathrm{C}$ ): Biomass char produced at $800^{\circ} \mathrm{C}$ performed comparably with ACs. The adsorption of PAHs in gaseous phase on ACs and chars was investigated in the works gathered in Table 3. Mastral et al. investigated the matter testing many varieties of carbon materials for adsorption of PAHs with 2-4 rings $[9,16,17,31,48,49]$ and found that the adsorption capacity of ACs was mostly dependent on their porous-textural characteristics, especially microporosity (or the ratio between the micropore volume to the total pore volume). Specifically, a large micropore volume enhanced the adsorption of pure multi ring compounds $[17,48]$ and their binary mixtures [49]. The adsorption of larger molecules such as phenanthrene and pyrene was favored by large micropores diameters $(>0.7 \mathrm{~nm})$ and by mesoporosity. Mesopores helped accessing the micropores and promoted multilayer 
interactions [49]. Each compound appeared to have specific needs in terms of pore size distribution, for being optimally adsorbed: for example, larger PAHs were found to be adsorbed more easily on the surface of tested ACs [48]. The role of surface chemistry of chars was investigated by García et al.[50], by measuring the adsorption of phenanthrene on $\mathrm{AC}$ with different degrees of surface oxidation: results showed that adsorption capacity is lower for $\mathrm{AC}$ with a higher content of surface oxygen groups, which means that the increased polarity of the surface hinders adsorption [50]. These results were later confirmed by Lillo Ródenas et al.[51]. They studied the adsorption of benzene and toluene on ACs with different porosities and with a reduced content of surface oxygen groups. Adsorption capacities for the two molecules varied on the same char. Narrow microporosity $(<0.7 \mathrm{~nm})$ was found to govern the adsorption of benzene, while all micropores $(<2 \mathrm{~nm})$ participated in the adsorption of toluene. Oxygen functional groups were removed from the char surface by heating to $900^{\circ} \mathrm{C}$ : thermally treated $\mathrm{AC}$ always showed an increased adsorption capacity. The negative effect of oxygen surface groups was explained with the interaction between aromatic rings of the adsorbate and electronrich regions of the graphene layers: the oxygen groups withdraw electrons from such layers, hindering the interaction with the adsorbate.

$\mathrm{Hu}$ et al.[15] also compared the adsorption on ACs, focusing on their interaction with phenol, naphthalene, ocresol and 1-methylnaphthalene. Interestingly, tars containing methyl groups were found to be adsorbed more efficiently in comparison with phenol and naphthalene. The authors suggest that this may be due to interaction between the methyl groups and the hydrophobic functional groups on the surface of the ACs. In agreement with Mastral et al., naphthalene was adsorbed better on microporous AC. The average pore diameter was found to influence the adsorption capacity, depending on the molecular shape and dimensions of the adsorbate: the two most favorable ACs for model tars adsorption had a specific surface area of about $1100 \mathrm{~m}^{2} / \mathrm{g}$ and an average pore size of 1.2 and $1.9 \mathrm{~nm}$.

In conclusion, to achieve high adsorption of aromatics, chars should have:

(i) Large specific surface area (BET with $\mathrm{N}_{2}$ around $1000 \mathrm{~m}^{2} / \mathrm{g}$ )

(ii) Low content of oxygen-containing surface groups

(iii) Large micropore volume $\left(\mathrm{N}_{2}\right.$ measured $\left.>0.3 \mathrm{~cm}^{3} / \mathrm{g}\right)$

(iv) Appropriate pore size distribution

The last parameter varies according to the molecules to be adsorbed: narrow microporosity can induce diffusional problems for large molecules (pyrene), whereas it promotes the adsorption of smaller molecules such as benzene. 


\subsection{Chemical adsorption and catalysis}

When reaction temperature is above $500-600^{\circ} \mathrm{C}$, chemisorption of aromatics can take place possibly followed by catalyzed reactions resulting in carbon deposition with release of products as $\mathrm{H}_{2}, \mathrm{CO}$ or $\mathrm{CO}_{2}$ (depending on the reaction atmosphere). An overview of the conditions of experiments at high temperatures is given in Table 4.

The effect of temperature on the reaction pathways taking place at the char surface were investigated by Egsgaard et al.[52]. They evaluated the irreversible binding of aromatic compounds on wood char up to $800^{\circ} \mathrm{C}$, by using a small char bed $(6 \mathrm{~g})$. The breakthrough of the model compounds was observed by stable isotope dilution analysis: binding within the bed was measured by the ${ }^{13} \mathrm{C}$ content of the char using ${ }^{13} \mathrm{C}_{6}$-benzene as a tracer. Starting already at $600-650^{\circ} \mathrm{C}$ char was able to bind tars, with increasing efficiency at higher temperature (up to $800^{\circ} \mathrm{C}$ ). It was observed that, at $700-800^{\circ} \mathrm{C}$, aromatics were covalently bound to the char surface by radical reactions, becoming part of the char. Naphthalene and phenanthrene were bound more efficiently than lighter compounds whereas phenol showed a different behavior. None of the introduced phenol could be collected after the char bed, partly because of decarbonylation and conversion to naphthalene. Such results suggest that in presence of a gasifying agent, aromatics could form covalent bonds with the char bed, while carbon could simultaneously be removed by gasification reactions in what the authors call a "living char bed".

Several studies have focused on the evaluation of the achievable conversion values for tar model compounds over char, depending on the properties of char and on the reaction conditions.

The catalytic effect of wood char in cracking and reforming of phenol and naphthalene was investigated by ElRub et al.[53]. The activities of pine wood char, commercial biochar and pine wood ashes were compared with common catalysts for tar removal, by measuring the change in concentration between inlet and outlet of a heated reactor. At $700^{\circ} \mathrm{C}$, over commercial biochar, $82 \mathrm{wt} \%$ of phenol and $99.6 \mathrm{wt} \%$ of naphthalene were converted. For naphthalene, biomass char showed the second highest activity among the tested catalysts, after the nickel catalyst. Pure biomass ash produced at $600^{\circ} \mathrm{C}$ showed a lower activity for naphthalene conversion in comparison with biomass char. This suggests that the carbon structure has a role itself in the enhancement of the catalytic activity, acting as a support for the inorganics contained in the parent feedstock (in this case $\mathrm{MgO}, \mathrm{CaO}, \mathrm{K}_{2} \mathrm{O}$ ).

These results validate the hypothesis that char has a catalytic effect on decomposition of tars, but the mechanism of the process is not clarified. Hosokai et al.[37] provided a more detailed description of the decomposition process. They monitored the decomposition rate of model tars over char and the concurrent formation rate of $\mathrm{CO}, \mathrm{CO}_{2}$ and $\mathrm{CH}_{4}$ under different atmospheres: $\mathrm{N}_{2}, \mathrm{~N}_{2} /$ steam, and $\mathrm{N}_{2} / \mathrm{H}_{2} /$ steam. Under all conditions, aromatics were found to decompose mainly by deposition on the char surface by coking (Reaction 2), and not by steam reforming (Reaction 3).

$\mathrm{C}_{\mathrm{m}} \mathrm{H}_{\mathrm{n}}$ (aromatics) $=\mathrm{C}_{\mathrm{m}} \mathrm{H}_{\mathrm{x}}($ coke $)+(\mathrm{n}-\mathrm{x}) / 2 \mathrm{H}_{2}$

(Coking/Cracking) Reaction 2

$\mathrm{C}_{\mathrm{m}} \mathrm{H}_{\mathrm{n}}$ (aromatics) $+\mathrm{H}_{2} \mathrm{O}=(\mathrm{m}+\mathrm{n} / 2) \mathrm{H}_{2}+\mathrm{mCO}$

(Steam Reforming) Reaction 3 
Micropores constituted active sites for deposition. Deactivation of char was observed under $\mathrm{N}_{2}$ atmosphere, whereas catalytic activity of char was maintained in presence of steam: gasification reactions enhanced the formation of micropores, preventing the blockage of active sites by coking. For this reason, it is suggested that the gasification rate should be equivalent or greater than the carbon deposition rate, in order to preserve the catalytic activity of char. On the other hand, the addition of $\mathrm{H}_{2}$ resulted in a slower, but still extensive, decomposition of aromatics. For benzene and naphthalene, lower inlet concentrations led to increased conversion: the initial concentration appeared to be a factor influencing the decomposition.

It is concluded that, if char has a sufficiently large micropore surface area, naphthalene can decompose completely at $750^{\circ} \mathrm{C}$, with a residence time of $0.2 \mathrm{~s}$. Naphthalene, phenol and phenanthrene can reach almost total conversion at $800-900^{\circ} \mathrm{C}$ with a steam concentration of $15.5 \% \mathrm{v} / \mathrm{v}$. Aromatics with more rings per molecule, hence phenanthrene and pyrene, were found to decompose more rapidly than lighter compounds.

Some of these results were verified by Fuentes Cano et al.[38]. Using a laboratory fixed bed reactor, they investigated the influence of temperature, steam concentration in the gas on the decomposition rate of toluene and naphthalene, and proposed kinetic expressions to describe the process. Tests were run on three chars originating from various materials and with different surface structure, but the parent material of char did not significantly affect the tar conversion. At $750^{\circ} \mathrm{C}$ the conversion rate reached $0.8 \%$ for toluene and nearly $100 \%$ for naphthalene. Above $850^{\circ} \mathrm{C}$, the decomposition of both compounds was fast and almost complete. However, continuous deactivation of the char activity was observed in both cases. In contrast, at $950^{\circ} \mathrm{C}$, and with a steam concentration of $15 \% \mathrm{v} / \mathrm{v}$ in the gas, the activity of char was maintained. In general, higher temperatures led to a higher conversion and a lower degree of char deactivation with time. The authors propose a two-step conversion mechanism:

(i) tar deposition on active sites and polymerization, with $\mathrm{H}_{2}$ and carbon deposition;

(ii) gasification of deposited carbon.

Such steps retrace the mechanism proposed by Hosokai et al.[37], a mechanism which is also corroborated by Nitsch et al.[54], who further investigated the role of steam in the interaction between tars and the char surface. Phenol degradation was measured over a fixed bed of char in $\mathrm{N}_{2}$ atmosphere, and with injection of steam and $\mathrm{H}_{2}$. In inert atmosphere, a large amount of phenol was observed in the outlet stream, and coking on micropores was evident. Addition of $\mathrm{H}_{2}$ did not show any major effect on tar reforming. In contrast, in the presence of steam, char showed a strong catalytic activity for phenol removal.

Huang et al.[55] measured the decomposition of toluene over the surface of sewage sludge char (SSC), in $\mathrm{N}_{2}$ atmosphere. They compared the activity of SSC with bottom ashes from a waste incinerator, dolomite and catalyst $\mathrm{NiO} / \gamma-\mathrm{Al}_{2} \mathrm{O}_{3}$. The latter one produced the highest toluene conversion ratio, followed by dolomite, SSC and bottom ashes. SSC gave a conversion rate as high as $94.5 \%$ at $950^{\circ} \mathrm{C}$. The conversion increased significantly 
when the temperature was raised from $750^{\circ} \mathrm{C}$ to $950^{\circ} \mathrm{C}$, and since the $\mathrm{H}_{2}$ yield followed the same trend in presence of a catalyst, the authors infer that all tested materials promoted cracking of toluene. In all cases coke deposition occurred, followed by a decrease in BET area. The same phenomenon was also observed in further experiments by the same research group [56], where the effect of the addition of $\mathrm{H}_{2}, \mathrm{CO}, \mathrm{CO}_{2}$, steam and $\mathrm{HCl}$ was studied on tar cracking and conversion, char pore structure and stability have been examined. The addition of $\mathrm{CO}_{2}$ and $\mathrm{H}_{2} \mathrm{O}$ favored the further reaction of deposited coke thus limiting the loss of surface area. At $950^{\circ} \mathrm{C}$ and in presence of $\mathrm{CO}_{2}$, and $\mathrm{H}_{2} \mathrm{O}$ mixed with $\mathrm{N}_{2}$, the toluene conversion reached $97.1 \%$. The authors surmise that $\mathrm{H}_{2} \mathrm{O}$ plays a crucial role in the tar cracking process as it takes part in steam reforming as well as in water gas and water-gas shift (Reactions 4-5).

$\mathrm{C}+\mathrm{H}_{2} \mathrm{O} \rightarrow \mathrm{H}_{2}+\mathrm{CO}$

(Water gas) Reaction 4

$\mathrm{CO}+\mathrm{H}_{2} \mathrm{O} \rightarrow \mathrm{H}_{2}+\mathrm{CO}_{2}$ (Water-gas shift) Reaction 5

The addition of $\mathrm{HCl}$ (which is a common compound produced from municipal solid waste gasification) had a negative effect on the activity of SSC, because it induced the nucleation of chlorides that participated in blocking the pores. In agreement with Fuentes Cano et al.[38], they observed that presence of $\mathrm{CO}_{2}$ and $\mathrm{H}_{2} \mathrm{O}$ and higher temperatures prevent deactivation of char.

The decomposition of toluene over char was also investigated by Bhandari et al.[57] at 700 and $800^{\circ} \mathrm{C}$ in a fixed bed reactor. The activity of gasification-derived biochar was compared with the activity of the same material after activation and after being coated with citric acid to obtain an acidic carbon surface. The toluene conversion was measured in $\mathrm{N}_{2}$ atmosphere: the three materials were effective in reducing the toluene concentration with conversion in the range 79-92\%. The average conversion was higher for activated carbons than for raw biochar: $86 \%$ against $9 \%$ at $700^{\circ} \mathrm{C}$. The acidification of the surface improved the conversion of toluene only at $800^{\circ} \mathrm{C}$. In contrast with other studies, the addition of artificial syngas was not beneficial but slightly decreased the conversion rate in the range $69-88 \%$. According to the authors, this effect was due to the adsorption of the gases on the carbon surface. However, the composition of the artificial syngas could have affected the results, particularly because of the abundance of $\mathrm{CO}$. For comparison, the compositions of artificial syngases used in the studies of Bhandari et al.[57] and Lu et al.[56] are reported in Table 5. Activated carbon with acidic surface was less efficient in toluene removal in comparison with the other tested chars; however, the authors suggest that the increased acidity could be useful for removing $\mathrm{NH}_{3}$ in the producer gas. The significant difference in the performance of raw biochar and activated biochar is ascribed to the low surface area $\left(64 \mathrm{~m}^{2} / \mathrm{g}\right)$ and pore volume $\left(0.09 \mathrm{~cm}^{3} / \mathrm{g}\right)$ of the raw material, whereas the tested $\mathrm{AC}$ had a pore volume five times higher and a BET surface of $944 \mathrm{~m}^{2} / \mathrm{g}$. 
The effectivity of biochar in enhancing the conversion of toluene was also reported by Mani et al.[58], who measured a conversion ratio of $94 \%$ at $900^{\circ} \mathrm{C}$ in $\mathrm{N}_{2} / \mathrm{H}_{2} \mathrm{O}$ atmosphere, with benzene as intermediate product of the cracking reactions. Formation of benzene as a product of toluene decomposition was also observed by Korus et al.[59]. During tests in the temperature range $650-950{ }^{\circ} \mathrm{C}$ under inert atmosphere, coke deposition on the surface of AC was measured simultaneously with the benzene production: these two effects resulted to be products of competing pathways of toluene decomposition. The measured conversion of toluene was over $90 \%$ when the temperature was $800^{\circ} \mathrm{C}$ and higher. Conversion was very efficient only as long as the AC surface was active (20 minutes). As soon as the coke deposition became hindered by coking on the AC surface, benzene formation was enhanced. An overview of the toluene conversion ratios obtained over different chars can be found in Table 6.

Naphthalene is a widely used model tar, as it represents one of the most abundant and recalcitrant components of the tar mixture in producer gas. Results on naphthalene conversion efficiencies are gathered in Table 7. Zhang et al.[39] compared the heterogeneous cracking of naphthalene over char with homogeneous decomposition in inert atmosphere. Three different chars were tested: rice straw char, rice straw char loaded with $\mathrm{Ni}\left(\mathrm{NO}_{3}\right)_{2}$ and waterwashed char. Heterogeneous conversion was generally higher than homogeneous conversion, but char showed decreased catalytic activity with time, accompanied by a lower BET surface area. In agreement with previous works, this effect was attributed to the carbon deposition on the active sites of the surface, which is identified as the main decomposition pathway. Nickel-loaded char showed a higher initial activity but a more rapid deactivation, whereas water-washed char induced a generally lower naphthalene conversion in comparison with original rice straw char. Addition of artificial syngas (a mixture of $\mathrm{H}_{2}, \mathrm{CO}, \mathrm{CO}_{2}$ and $\mathrm{CH}_{4}$ ) resulted in a delayed deactivation of the original rice straw char. Zhang et al.[39] formulated the heterogeneous catalysis for naphthalene decomposition over char in 3 steps:

(i) adsorption on active sites;

(ii) dissociation into radicals (naphthyl and hydrogen);

(iii) desorption of radicals.

In an inert atmosphere, radicals react with each other in polymerization and soot formation. If oxidative species are present, they generate mono-ring aromatics, hydrocarbons and gases.

Di Gregorio et al.[23] focused on naphthalene as well and tested the effectivity of three commercial ACs for adsorption and cracking. The characterization of ACs showed that they had different surface areas and pore size distributions and contained varying amount of inorganics on the surface. The comparison between the performances of the ACs showed that $\mathrm{Fe}, \mathrm{Mg}$ and $\mathrm{Al}$ enhance the cracking of tars. The highest and most stable naphthalene conversion in a 4 hours test was obtained on AC with larger specific surface area accompanied by a high micropore volume and appropriate pore size distribution (as described by [17] and [15]). Complete removal 

for one of the tested ACs, also at higher concentrations (up to $176.7 \mathrm{~g} / \mathrm{Nm}^{3}$ ). The cracking efficiency decreased with higher concentrations, in agreement with the findings from Hosokai et al.[37].

Likewise Nestler et al.[60] investigated the catalytic activity of biochar towards naphthalene decomposition in inert atmosphere. Spruce wood was carbonized at $500^{\circ} \mathrm{C}$ and $800^{\circ} \mathrm{C}$, and part of it was $\mathrm{CO}_{2}$-activated. The activities of these chars were compared with that of commercial $\mathrm{AC}$ at $850{ }^{\circ} \mathrm{C}$ and $1050^{\circ} \mathrm{C} . \mathrm{CO}_{2}$ activation treatment increased the BET surface area (Table 7) and the microporosity (surface and volume) of char, resulting in an improved naphthalene conversion. All chars showed deactivation with time, due to coking and blocking of the active sites. Particularly, non-activated wood chars showed a low conversion rate and a fast deactivation, probably due to low pore volume $\left(\sim 0.15 \mathrm{~cm}^{3} / \mathrm{g}\right)$. In contrast, activated wood chars with a higher surface area and a larger pore volume $\left(\sim 0.25 \mathrm{~cm}^{3} / \mathrm{g}\right)$ performed similarly to the commercial AC.

Feng et al.[61] used K-loaded and Ca-loaded rice straw char to investigate the influence of AAEM on the char catalytic activity towards tar reforming, under $\mathrm{H}_{2} \mathrm{O}$ or $\mathrm{CO}_{2}$ atmosphere. Toluene, naphthalene and phenol were converted more efficiently in presence of steam, on the surface of K-loaded char. The authors suggest that carbon deposition is promoted by $\mathrm{C}-\mathrm{O}-\mathrm{K}$ clusters on the char surface, which constitute active sites. In contrast, Ca provides fewer active sites, as it bonds to the char with strong double bonds.

Overall, these results indicate that the char activity for tar model compounds decomposition is affected by the volume and size distribution of the pores (especially micropores), but also the inorganics on the surface affect the catalytic activity for tar cracking. Indeed, the effect of the mineral composition of char on tar cracking was also investigated by Hervy et al.[62]. Ethylbenzene was used as a model compound for aromatic hydrocarbons, and its conversion was measured on three different chars produced from waste materials: wood pallets (WP), food waste (FW), sludge (S). The chars were produced with pure WP, and mixing FW/S and WP/FW/S. Chars were thoroughly characterized with various analytical techniques in order to establish their structural and chemical characteristics: significant differences were observed in the composition of the inorganic fraction and in the carbon structure. In comparison with WP char, char produced from a mixture of FW and S was more effective in removing ethylbenzene from the gas stream, enhancing the cracking onto styrene, benzene, ethylene and toluene. The stronger catalytic activity was partly ascribed to a more disordered carbonaceous structure, but mostly to the higher ash content including $\mathrm{Ca}, \mathrm{P}, \mathrm{Al}$ and $\mathrm{K}$ oxides which were well dispersed on the surface.

The overview of these works shows that the effectiveness of biochar in removing tar compounds in gas phase is comparable to that of commercial catalysts: conversion of model compounds can reach $100 \%$ under favorable conditions. However, the interaction between tars and char surface implies a complicated synergy of gas-phase and solid-gas reactions, and they can vary significantly depending on the char characteristics and on the reaction 
conditions: the achievable conversion is difficult to predict. It is evident that temperature plays an important role, and in order to reach a conversion rate over $90 \%$, a minimum temperature of $800^{\circ} \mathrm{C}$ is needed.

The presence of reforming agents $\left(\mathrm{H}_{2} \mathrm{O}, \mathrm{CO}_{2}\right)$ appears to induce higher conversions, whereas addition of $\mathrm{H}_{2}$ results slightly detrimental for both toluene [56] and naphthalene [37] conversions. This effect, even if not strong, could be due to the inhibitory effect of $\mathrm{H}_{2}$ on gasification reactions also observed by Barrio et al.[63].

In general, naphthalene shows higher conversions in comparison to toluene, revealing a preferential interaction of char with heavier aromatics. This is in agreement with the findings of Hosokai et al.[37], who stated that molecules with more fused rings were decomposed faster, and with the preferential adsorption for PAH observed on AC by Mastral et al.[17]. Selectivity towards multi-ring aromatics has also been observed by researchers working with thermal decomposition of pyrolysis-derived tars [64,65].

Such evidence suggests a beneficial effect of partial oxidation of tars before contacting the char: oxidation modifies the tar composition, converting oxygenated compounds into simple PAHs, especially naphthalene [66].

\subsubsection{Determination of kinetic parameters for Toluene and Naphthalene decomposition}

Only a few papers have investigated kinetic parameters for decomposition of model tars, focusing on the kinetics of toluene and naphthalene $[38,53,58,67]$. For both compounds, the rate equations were found to follow first order kinetics, showing a linear increase in the reaction rate when increasing the inlet concentration.

$-r_{\text {tar }}=k *\left[C_{\text {tar }}\right]$

(Equation 2)

where $\mathrm{r}_{\mathrm{tar}}$ is the tar decomposition rate, $\mathrm{k}$ is the rate constant and $\mathrm{C}_{\mathrm{tar}}$ is the model compound concentration in the gas flow. The rate constant was estimated according to Arrhenius' law

$K=A * e^{\frac{-E_{a}}{R T}}$

(Equation 3)

El-Rub et al.[53] evaluated the kinetic parameters of naphthalene when reacting on commercial biomass char, whereas Mani et al.[58] studied the reaction rate of toluene steam reforming over pine bark biochar. The same research group further investigated the change in the kinetics of toluene steam reforming when the same biochar was impregnated and calcined with iron. Results were published by Kastner et al.[68]. The effect of Fe was to increase the reaction rate and to lower the activation energy. Table 8 reports the kinetics values estimated from experiments on model tar decomposition.

These kinetic expressions only consider the initial activity of char for tar decomposition and they do not take into account any deactivation effect.

Fuentes Cano et al.[38] proposed an extended kinetic expression describing the effect of deactivation, introducing the activity factor a: the reaction rate is therefore expressed as in Equation 4

$-r_{\text {tar }}=k *\left[C_{\text {tar }}\right] * a$

(Equation 4) 
Where $\mathrm{a}=1$ for fresh char; $\mathrm{a}<1$ for partially deactivated char. Activity of char is defined as in Equation 5

$a=\frac{-r_{\text {tar }, t}}{-r_{\text {tar }, 0}}$

(Equation 5)

Where $r_{\text {tar, }}$ is the reaction rate at time $t$ and $r_{\text {tar, }, 0}$ is the initial reaction rate. The activity of char as a function of time was fitted to the empirical expression in Equation 6.

$a=\frac{1}{1+k_{d} t^{p}}$ with $p=p_{1}+p_{2}\left(\frac{T}{1023}\right)$

(Equation 6)

Where $\mathrm{k}_{\mathrm{d}}, \mathrm{p}_{1}$ and $\mathrm{p}_{2}$ are empirical parameters, and $\mathrm{T}$ is the char bed temperature, expressed in Kelvin. Comparison of the experimental results with this kinetic model showed a good agreement, being most data within $\pm 20 \%$ of error, as showed in Figure 3 .

Based on these results, the kinetics of tar decomposition on char surfaces should be further investigated with the aim to develop accurate kinetic models and describe the reaction mechanism for different compounds.

\subsubsection{Carbon deposition and char deactivation}

The main reaction pathway for model tars decomposition over char appears to be carbon deposition by polymerization (or coking) on the active sites of the surface. This was observed for both alkanes and aromatics: Figure 4 shows spent char samples after propane and methane exposure, Figure 5 and 6 show coke formation after toluene decomposition, whereas the effect of naphthalene exposure on the char structure are captured in Figure 7 .

Coking was often found to cause deactivation of the carbon surface, especially under inert atmosphere. SEM analysis has been widely applied for visualization of deposited carbon $[41,57,58,60]$ : Carbon deposits take up different shapes depending on the reaction conditions. The polymerization is enhanced by specific active sites, as visible in Figure 4(b) for methane deposition.

Both Hosokai et al.[37] and Nestler et al.[60] observed that on deactivated char, micropore volume was reduced, whereas mesopore volume remained unaltered. This result clearly indicates that micropores are active sites for carbon deposition. This also explains the fact that deactivation is faster on microporous carbons under inert atmosphere, when the deposited carbon quickly blocks the micropore mouths [60]. In contrast, in presence of $\mathrm{H}_{2} \mathrm{O}$ and $\mathrm{CO}_{2}$, the activity of char is maintained in time and the yield of stable gases is improved, particularly $\mathrm{H}_{2}$, $\mathrm{CO}, \mathrm{CO}_{2}$ and, to a lesser extent, $\mathrm{CH}_{4}$. 
The overview of the above summarized studies outlines the state-of-the -art in the understanding of interactions between tar compounds and carbonaceous surface. All in all, it is evident that char has a beneficial effect on the removal or conversion of tar model compounds from a gaseous flow, and could be used as adsorbent or catalyst for gas cleaning. Chars produced with gasification and pyrolysis can be comparable to activated carbons in terms of effectivity for decomposition of model tars. The processes taking place at the surface strongly depend on the reaction conditions: adsorption is predominant at lower temperatures, whereas reforming reactions require higher temperatures and presence of $\mathrm{CO}_{2}$ or $\mathrm{H}_{2} \mathrm{O}$ in the gas phase. Biomass char can catalyze the decomposition of $\mathrm{CH}_{4}$ and $\mathrm{C}_{3} \mathrm{H}_{8}$ producing $\mathrm{H}_{2}$. The induced conversion of toluene and phenol can be higher than $80 \%$ at $800^{\circ}$, whereas naphthalene can reach $100 \%$ conversion upon contact with the char surface.

Biomass char can be suitable to be used as a catalyst in producer gas treatment for removing tars, especially multi-ring aromatics: indeed, biochar appears to catalyze tars cracking and reforming due to a synergy of surface chemistry and morphology. However, the properties of the char surface and the reaction conditions must be optimized in order to achieve complete conversion

In general, the abundance of active sites is favored by defects in the carbon structure (microcrystallinity, turbostratic carbon), and in presence of inorganic impurities. In particular, AAEM and metals (e.g. Fe, Al) appear to be effective in forming active sites, when they are well dispersed at accessible sites (micropores) on the surface. As a matter of fact, pure biomass ash always showed a lower activity in comparison with biomass char $[25,53,55]$, indicating that the presence of carbon improves the catalytic activity acting as support.

It is difficult to quantify the effect of oxygen-containing functional groups, because at high temperature they are disrupted and simultaneously created by carbon deposition. For $\mathrm{CH}_{4}$ decomposition they were found to have an effect only in the initial activity of char [34] or no effect at all [25], and to have a negative effect on PAHs adsorption [51] and toluene decomposition [57]. In general, their effect on the decomposition of both alkanes and aromatics appears as secondary.

In contrast, the surface area (generally quantified with BET values) emerges as an important factor, together with the pore volume and the pore size distribution: the ratio between the micropore volume and the total pore volume should be high, as active sites appear to be housed in the micropores. A good pore structure enhances the long term activity of biochar as a catalyst, especially in presence of a reforming agent. In inert atmosphere, coking on the char surface leads to blocking of the active sites. Therefore, to prevent deactivation, the following points should be considered:

(i) The char should have a high micropore volume, but the pore size distribution should include mesopores, so that diffusion is not hindered. 
Steam or dry reforming can be useful to create a dynamic equilibrium of coke deposition and gasification in the catalytic bed: the rate of gasification should be equal or higher to the rate of coke deposition, but not so high to quickly consume the solid bed.

An optimal solution for gas cleaning in biomass gasification would be the use of residual char as catalyst, possibly without further treatments. For the practical implementation of such solution, it would be useful to define correlations between the rate of tar decomposition, or the tar reactivity, and the char characteristics and reaction conditions, for representative model tars.

The reaction conditions to be considered should be:

- Temperature and pressure

- $\quad$ Gas phase composition $\left(\mathrm{N}_{2}, \mathrm{H}_{2} \mathrm{O}, \mathrm{H}_{2}, \mathrm{O}_{2}, \mathrm{CO}\right)$

- Tar species concentration

- $\quad$ Residence time

Determinant char properties that should be regarded are:

- $\quad$ Specific surface area (BET)

- Total pore volume

- Pore size distribution: micropores volume to total volume ratio, or average pore diameter

- Concentration of inorganic elements on the char surface

All of these parameters are interdependent, and together they influence the effectivity of model tar conversion. With this in mind, it would be beneficial to dedicate future research activities to testing of char beds for the cleaning of real producer gas, with the aim to optimize and balance tar conversion and char gasification for an effective and stable gas cleaning.

\section{Acknowledgements}

The authors thank Innovationsfonden for the financial support received as part of the project "SYNFUEL Sustainable synthetic fuels from biomass gasification and electrolysis" (4106-00006B). 


\section{References}

[1] Devi L, Ptasinski KJ, Janssen FJJG. A review of the primary measures for tar elimination in biomass gasiÿcation processes. Biomass and Bioenergy 2003;24:125-40.

[2] Brewer CE, Schmidt-Rohr K, Satrio JA, Brown RC. Characterization of Biochar from Fast Pyrolysis and Gasification Systems. Environ Prog Sustain Energy 2009;28:386-96.

[3] Benedetti V, Patuzzi F, Baratieri M. Characterization of char from biomass gasi fi cation and its similarities with activated carbon in adsorption applications. Appl Energy 2017:1-8.

[4] Köchling K, McEnaney B, Rozploch F, Fitzer E. International Committee for Characterization Terminology of Carbon “ First Publication of 30 Tentative Definitions .” Carbon N Y 1982;20:445-9.

[5] Köchling K, McEnaney B, Müller S, Fitzer E. International Committee for Characterization and Terminology of Carbon "First Publication of Further 24 Tentative Definitions". Carbon N Y 1985;23:601-3.

[6] Rodríguez-Reinoso F. The role of carbon materials in heterogeneous catalysis. Carbon N Y 1998;36:15975.

[7] Keiluweit M, Nico PS, Johnson M, Kleber M. Dynamic molecular structure of plant biomass-derived black carbon (biochar). Environ Sci Technol 2010;44:1247-53.

[8] Schimmelpfennig S, Glaser B. One Step Forward toward Characterization: Some Important Material Properties to Distinguish Biochars. J Environ Qual 2012;32.

[9] Mastral AM, García T, Murillo R, Callen MS, Lopez JM, Navarro M V. Development of efficient adsorbent materials for PAH cleaning from AFBC hot gas. Energy and Fuels 2004;18:202-8.

[10] Dasgupta K, Sathiyamoorthy D. Disordered carbon-its preparation, structure, and characterisation. Mater Sci Technol 2003;19:995-1002.

[11] European Biochar Foundation (EBC). Guidelines for a Sustainable Production of Biochar. Eur Biochar Found 2016.

[12] International Biochar Initiative. Standardized Product Definition and Product Testing Guidelines for Biochar That Is Used in Soil 2015:1-61.

[13] Bansal RC, Donnet J-B, Stoeckli F. Active Carbon. New York and Basel: Marcel Dekker, Inc.; 1988.

[14] Stoeckli HF. Microporous carbons and their characterization: The present state of the art. Carbon N Y 1990;28:1-6.

[15] Hu X, Hanaoka T, Sakanishi K, Shinagawa T, Matsui S, Tada M, et al. Removal of Tar Model Compounds Produced from Biomass Gasification Using Activated Carbons. J Japan Inst Energy 2007;86:707-7011.

[16] Mastral AM, García T, Murillo R, Callén MS, López JM, Navarro M V. Measurements of Polycyclic Aromatic Hydrocarbon Adsorption on Activated Carbons at Very Low Concentrations. Ind Eng Chem Res 2003:155-61. 
[17] Mastral A, García T, Callén M, Navarro M, Galbán J. Assessement of Phenanthrene Removal from Hot Gas by Porous Carbons. Energy \& Fuels 2001;15:1-7.

[18] Franz M, Arafat HA, Pinto NG. Effect of chemical surface heterogeneity on the adsorption mechanism of dissolved aromatics on activated carbon. Carbon N Y 2000;38:1807-19.

[19] Vidic RD, Suidan MT. Role of dissolved oxygen on the adsorptive capacity of activated carbon for synthetic and natural organic matter. Environ Sci Technol 1991;25:1612-8.

[20] Leng C-C, Pinto NG. Effects of surface properties of activated carbons on adsorption behavior of selected aromatics. Carbon N Y 1997;35:1375-85.

[21] Arafat HA, Franz M, Pinto NG. Effect of Salt on the Mechanism of Adsorption of Aromatics on Activated Carbon $\uparrow$ 1999:5997-6003.

[22] Cudahy JJ, Helsel RW. Removal of products of incomplete combustion with carbon. Waste Manag 2000;20:339-45.

[23] Gregorio F Di, Parrillo F, Salzano E, Cammarota F, Arena U. Removal of naphthalene by activated carbons from hot gas. Chem Eng J 2016;291:244-53.

[24] Liu W-J, Zeng F-X, Jiang H, Zhang X-S. Preparation of high adsorption capacity bio-chars from waste biomass. Bioresour Technol 2011;102:8247-52.

[25] Klinghoffer NB, Castaldi MJ, Nzihou A. Influence of char composition and inorganics on catalytic activity of char from biomass gasification. Fuel 2015;157:37-47.

[26] Min Z, Yimsiri P, Asadullah M, Zhang S, Li C-Z. Catalytic reforming of tar during gasification. Part II. Char as a catalyst or as a catalyst support for tar reforming. Fuel 2011;90:2545-52.

[27] Benedetti V, Patuzzi F, Baratieri M. Gasification char as a potential substitute of activated carbon in adsorption applications. Energy Procedia 2016;0.

[28] Qian K, Kumar A. Catalytic reforming of toluene and naphthalene (model tar) by char supported nickel catalyst. Fuel 2017;187:128-36.

[29] Font Palma C. Modelling of tar formation and evolution for biomass gasification: A review. Appl Energy 2013;111:129-41.

[30] Mastral AM, García T, Murillo R, Callén MS, López JM, Navarro M V. PAH Mixture Removal from Hot Gas by Porous Carbons . From Model Compounds to Real Conditions 2003:5280-6.

[31] Mastral AM, García T, Murillo R, Callen MS, Lopez JM, Navarro M V. Moisture effects on the phenanthrene adsorption capacity by carbonaceous materials. Energy and Fuels 2002;16:205-10.

[32] Muradov N. Hydrogen via methane decomposition : an application for decarbonization of fossil fuels. Int J Hydrogen Energy 2001;26:1165-75.

[33] Muradov N, Smith F, T-Raissi A. Catalytic activity of carbons for methane decomposition reaction. Catal Today 2005;102-103:225-33. 
[34] Moliner R, Suelves I, Lázaro MJ, Moreno O. Thermocatalytic decomposition of methane over activated carbons: Influence of textural properties and surface chemistry. Int J Hydrogen Energy 2005;30:293-300.

[35] Suelves I, Pinilla JL, Lázaro MJ, Moliner R. Carbonaceous materials as catalysts for decomposition of methane. Chem Eng J 2008;140:432-8.

[36] Dufour a., Celzard A, Fierro V, Martin E, Broust F, Zoulalian A. Catalytic decomposition of methane over a wood char concurrently activated by a pyrolysis gas. Appl Catal A Gen 2008;346:164-73.

[37] Hosokai S, Kumabe K, Ohshita M, Norinaga K, Li C, Hayashi J-I. Mechanism of decomposition of aromatics over charcoal and necessary condition for maintaining its activity. Fuel 2008;87:2914-22.

[38] Fuentes-Cano D, Gómez-Barea A, Nilsson S, Ollero P. Decomposition kinetics of model tar compounds over chars with different internal structure to model hot tar removal in biomass gasification. Chem Eng $\mathbf{J}$ 2013;228:1223-33.

[39] Zhang Y, Luo Y, Wu W, Zhao S, Long Y. Heterogeneous Cracking Reaction of Tar over Biomass Char, Using Naphthalene as Model Biomass Tar. Energy \& Fuels 2014;28:3129-37.

[40] Dufour A, Celzard A, Fierro V, Broust F, Courson C, Zoulalian A, et al. Catalytic conversion of methane over a biomass char for hydrogen production: deactivation and regeneration by steam gasification. Appl Catal A Gen 2015;490:170-80.

[41] Klinghoffer N, Castaldi MJ, Nzihou A. Catalyst Properties and Catalytic Performance of Char from Biomass Gasification. I\&Ec 2012:13113-22.

[42] Karatza D, Musmarra D. Fly Ash Capture of Mercuric Chloride Vapors from Exhaust Combustion Gas Environ. Sci. Technol. 1998;32:3999-4004.

[43] Lowell, S.; Shields, Joan E.; Thomas, Martin A.; Thommes M. Characterization of porous solids and powders: surface area, pore size and density. Kluwer Academic; 2004.

[44] Tsonopoulos C, Ambrose D. Vapor-Liquid Critical Properties of Elements and Compounds . 3 . Aromatic Hydrocarbons. J Chem Eng Data 1995:547-58.

[45] Lamichhane S, Krishna KCB, Sarukkalige R. Polycyclic aromatic hydrocarbons ( PAHs ) removal by sorption: A review. Chemosphere 2016;148:336-53.

[46] Li H, Qu R, Li C, Guo W, Han X, He F, et al. Selective removal of polycyclic aromatic hydrocarbons ( PAHs ) from soil washing effluents using biochars produced at different pyrolytic temperatures. Bioresour Technol 2014;163:193-8.

[47] Chen B, Zhou D. Transitional Adsorption and Partition of Nonpolar and Polar Aromatic Contaminants by Biochars of Pine Needles with Different Pyrolytic Temperatures. Environ Sci Technol 2008;42:5137-43.

[48] Mastral AM, García T, Callén MS, Navarro M V., Galbán J. Removal of naphthalene, phenanthrene, and pyrene by sorbents from hot gas. Environ Sci Technol 2001;35:2395-400.

[49] Mastral A, García T, Murrillo R, Callén MS, Lopez JM, Navarro M V, et al. Study of the Adsorption of Polyaromatic Hydrocarbon Binary Mixtures on Carbon Materials by Gas-Phase Fluorescence Detection. Energy \& Fuels 2003:669-76. 
[50] García T, Murillo R, Cazorla-Amorós D, Mastral AM, Linares-Solano A. Role of the activated carbon surface chemistry in the adsorption of phenanthrene. Carbon N Y 2004;42:1683-9.

[51] Lillo-Ródenas M, Cazorla-Amorós D, Linares-Solano A. Behaviour of activated carbons with different pore size distributions and surface oxygen groups for benzene and toluene adsorption at low concentrations. Carbon N Y 2005;43:1758-67.

[52] Egsgaard H, Ahrenfeldt J, Ambus P, Schaumburg K, Henriksen UB. Gas cleaning with hot char beds studied by stable isotopes. J Anal Appl Pyrolysis 2014;107:174-82.

[53] Abu El-Rub Z, Bramer EA, Brem G. Experimental comparison of biomass chars with other catalysts for tar reduction. Fuel 2008;87:2243-52.

[54] Nitsch X, Commandré J-M, Valette J, Volle G, Martin E. Conversion of Phenol-Based Tars over Biomass Char under H 2 and H 2 O Atmospheres. Energy \& Fuels 2014:28 (2014) 6936-6940.

[55] Huang Q, Lu P, Hu B, Chi Y, Yan J. Cracking of model tar species from the gasification of municipal solid waste using commercial and waste derived catalysts. Energy \& Fuels 2016:acs.energyfuels.6b00711.

[56] Lu P, Qian X, Huang Q, Chi Y, Yan J. Catalytic cracking of toluene as a tar model compound using sewage sludge derived char. Energy \& Fuels 2016:acs.energyfuels.6b01832.

[57] Bhandari PN, Kumar A, Bellmer DD, Huhnke RL. Synthesis and evaluation of biochar-derived catalysts for removal of toluene (model tar) from biomass-generated producer gas. Renew Energy 2014;66:34653.

[58] Mani S, Kastner JR, Juneja A. Catalytic decomposition of toluene using a biomass derived catalyst. Fuel Process Technol 2013;114:118-25.

[59] Korus A, Samson A, Szle A, Katelbach-woz A. Pyrolytic toluene conversion to benzene and coke over activated carbon in a fixed-bed reactor. Fuel 2017;207:283-92.

[60] Nestler F, Burhenne L, Amtenbrink MJ, Aicher T. Catalytic decomposition of biomass tars: The impact of wood char surface characteristics on the catalytic performance for naphthalene removal. Fuel Process Technol 2016;145:31-41.

[61] Feng D, Zhao Y, Zhang Y, Sun S, Meng S, Guo Y, et al. Effects of K and Ca on reforming of model tar compounds with pyrolysis biochars under H2O or CO2. Chem Eng J 2016;306:422-32.

[62] Hervy M, Berhanu S, Weiss-Hortala E, Chesnaud A, Gérente C, Villot A, et al. Multi-scale characterisation of chars mineral species for tar cracking. Fuel 2017;189:88-97.

[63] Barrio M, Gøbel B, Rimes H, Henriksen U, Hustad JE, Sørensen LH. Steam Gasification of Wood Char and the Effect of Hydrogen Inhibition on the Chemical Kinetics. Prog Thermochem Biomass Convers 2008:32-46.

[64] Boroson ML, Howard JB, Longwell JP, Peters W a. Heterogeneous cracking of wood pyrolysis tars over fresh wood char surfaces. Energy \& Fuels 1989;3:735-40.

[65] Krerkkaiwan S, Tsutsumi A, Kuchonthara P. Biomass derived tar decomposition over coal char bed. ScienceAsia 2013;39:511. 
[66] Ahrenfeldt J, Egsgaard H, Stelte W, Thomsen T, Henriksen UB. The influence of partial oxidation mechanisms on tar destruction in TwoStage biomass gasification. Fuel 2013;112:662-80.

[67] Juneja, Ankita; Mani, Sudhagar; Kastner J. Catalytic Cracking of Tar using BioChar as a Catalyst. ASABE Annu. Int. Meet., 2010.

[68] Kastner JR, Mani S, Juneja A. Catalytic decomposition of tar using iron supported biochar. Fuel Process Technol 2015;130:31-7. 


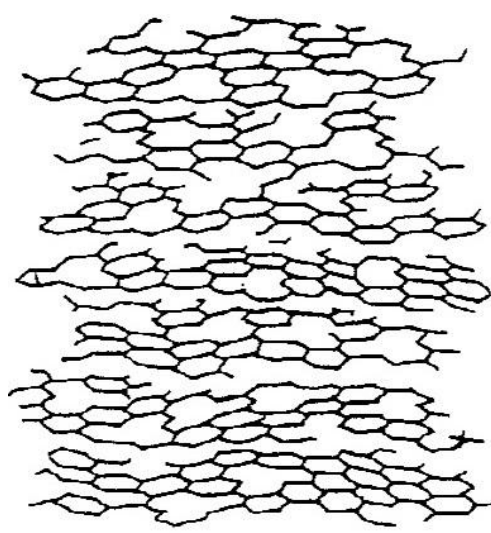

(a)

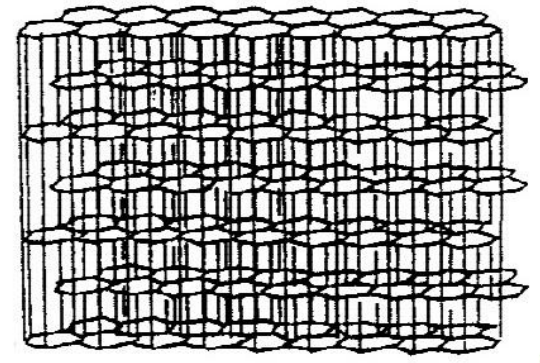

(b)

Figure 1: Schematic difference between turbostratic (a) and graphite (b) structure. (Adapted from [10] with permission from Taylor \& Francis Ltd.) 


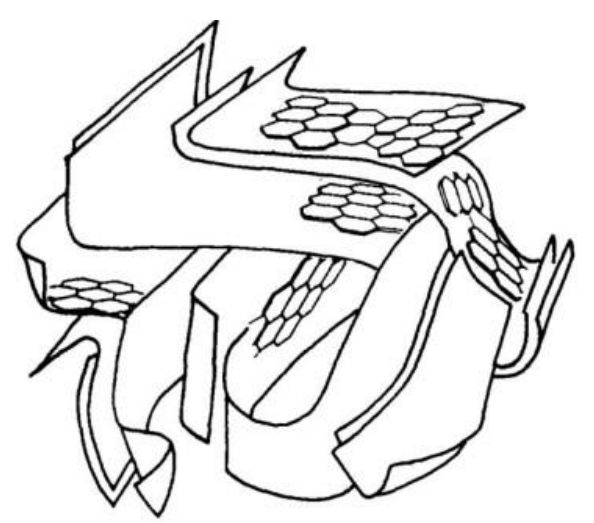

Figure 2: Schematic structure of AC. (Reprinted from [14], pag.2. Copyright 1990 Elsevier) 


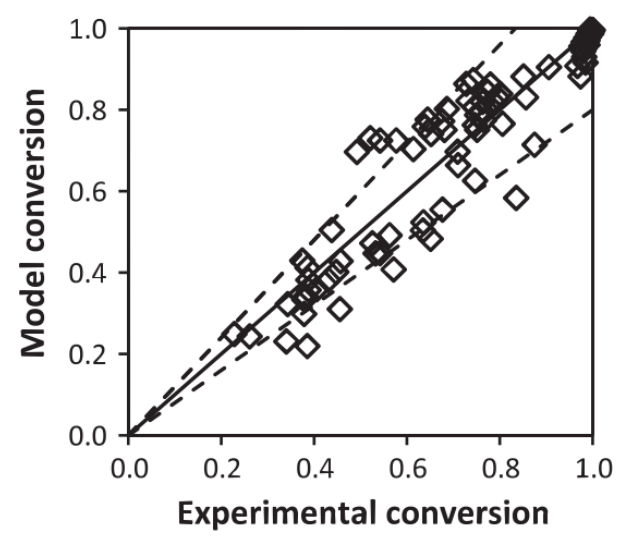

Figure 3: Comparison of kinetic model (heavy line) with experimental results (squares). Dotted lines show $\pm 20 \%$ deviation. (Reprinted from [38], pag.1233. Copyright 2013 Elsevier)

Figure 3 
Figure 4
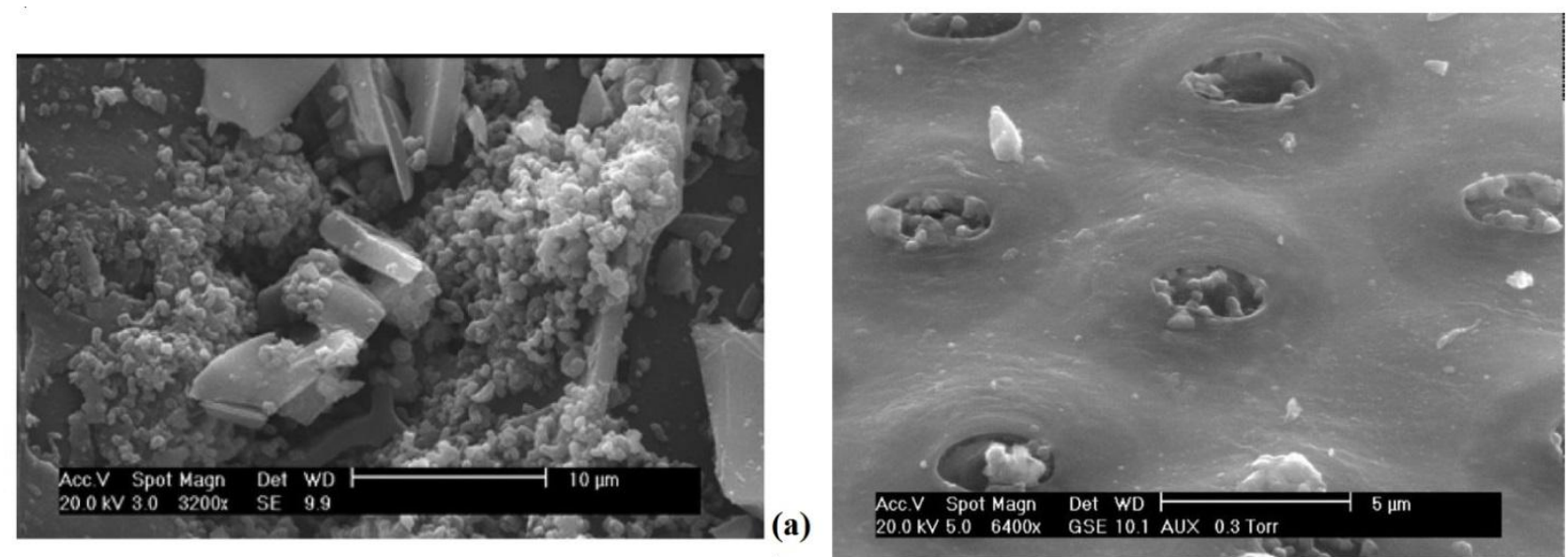

(b)

Figure 4: Carbon deposits on char after propane (a) and methane (b) catalytic decomposition. (Adapted with permission from [41] Copyright 2012 American Chemical Society). 


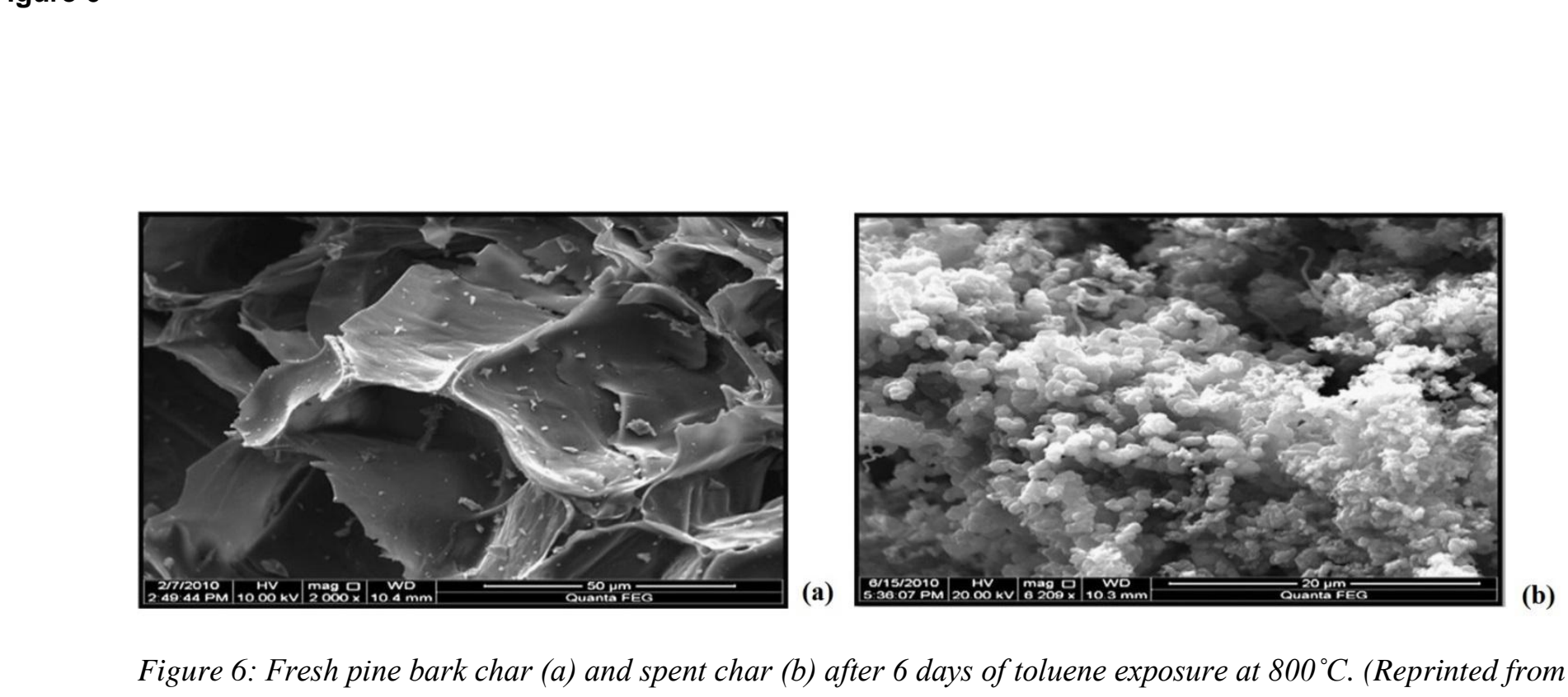

Figure $6:$ Fresh pine bark char (a) and spent char (b) after 6 days of toluene exposure at $800^{\circ} \mathrm{C}$. (Reprinted fro

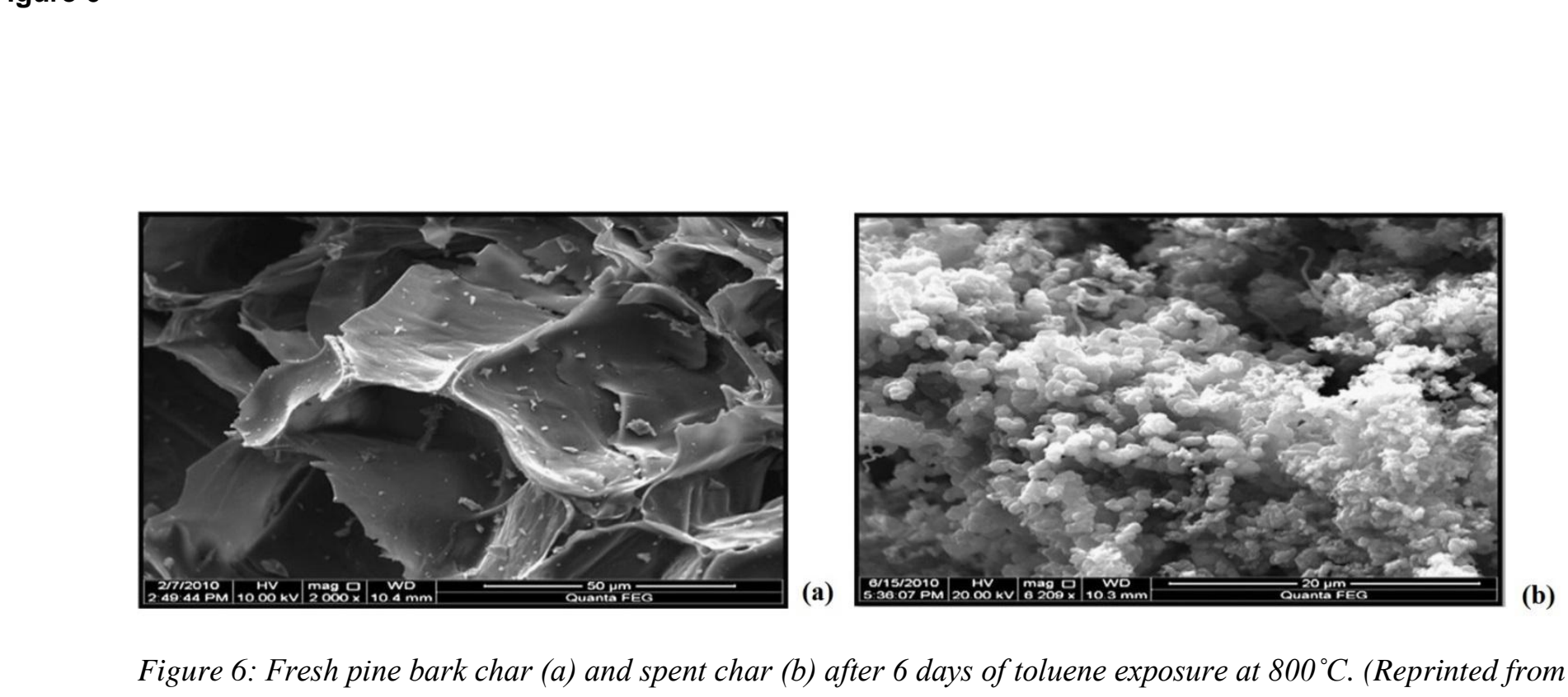

(b)

Figure 6: Fresh pine bark char (a) and spent char (b) after 6 days of toluene exposure at $800^{\circ} \mathrm{C}$. (Reprinted from

Figure 6: Fresh pine bark char (a) and s
[46], pag 124. Copyright 2013 Elsevier) . (4) (
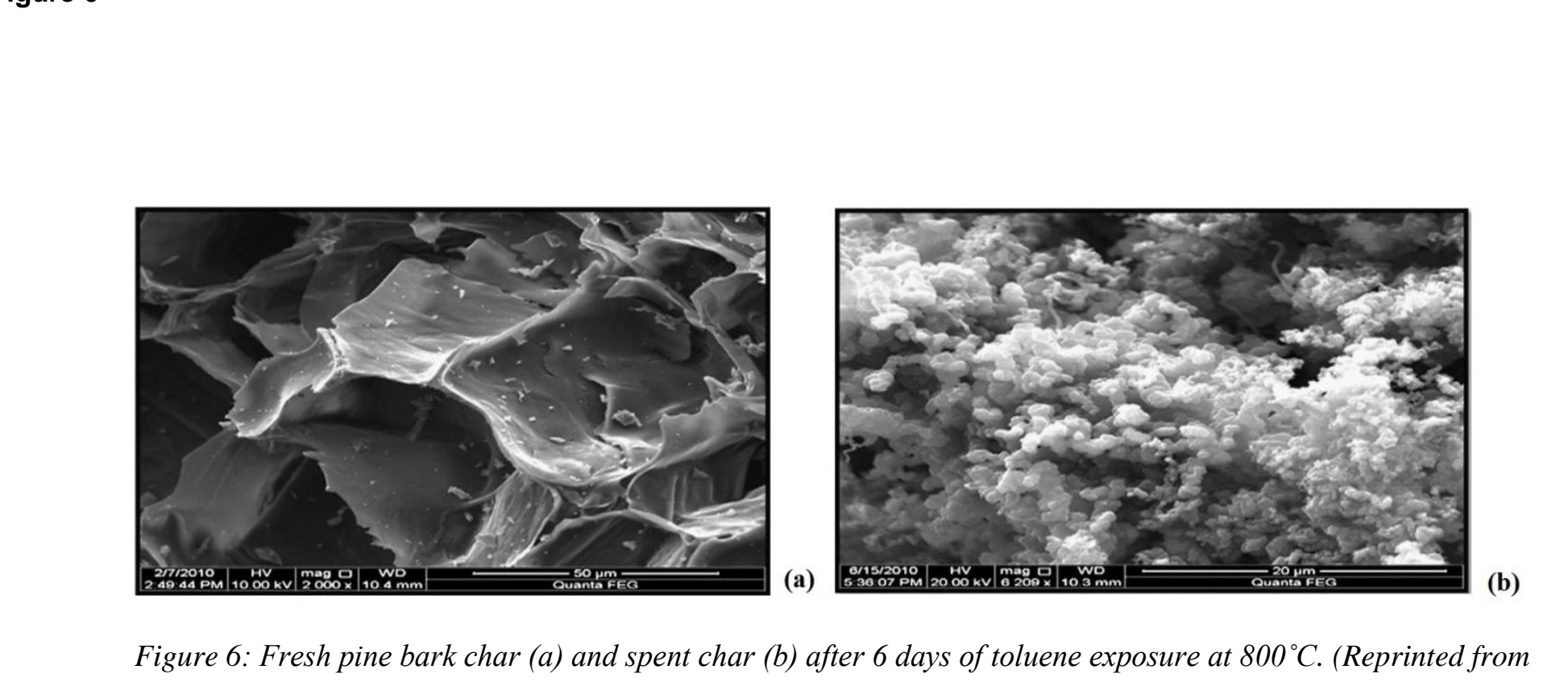

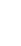

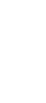


Figure 7
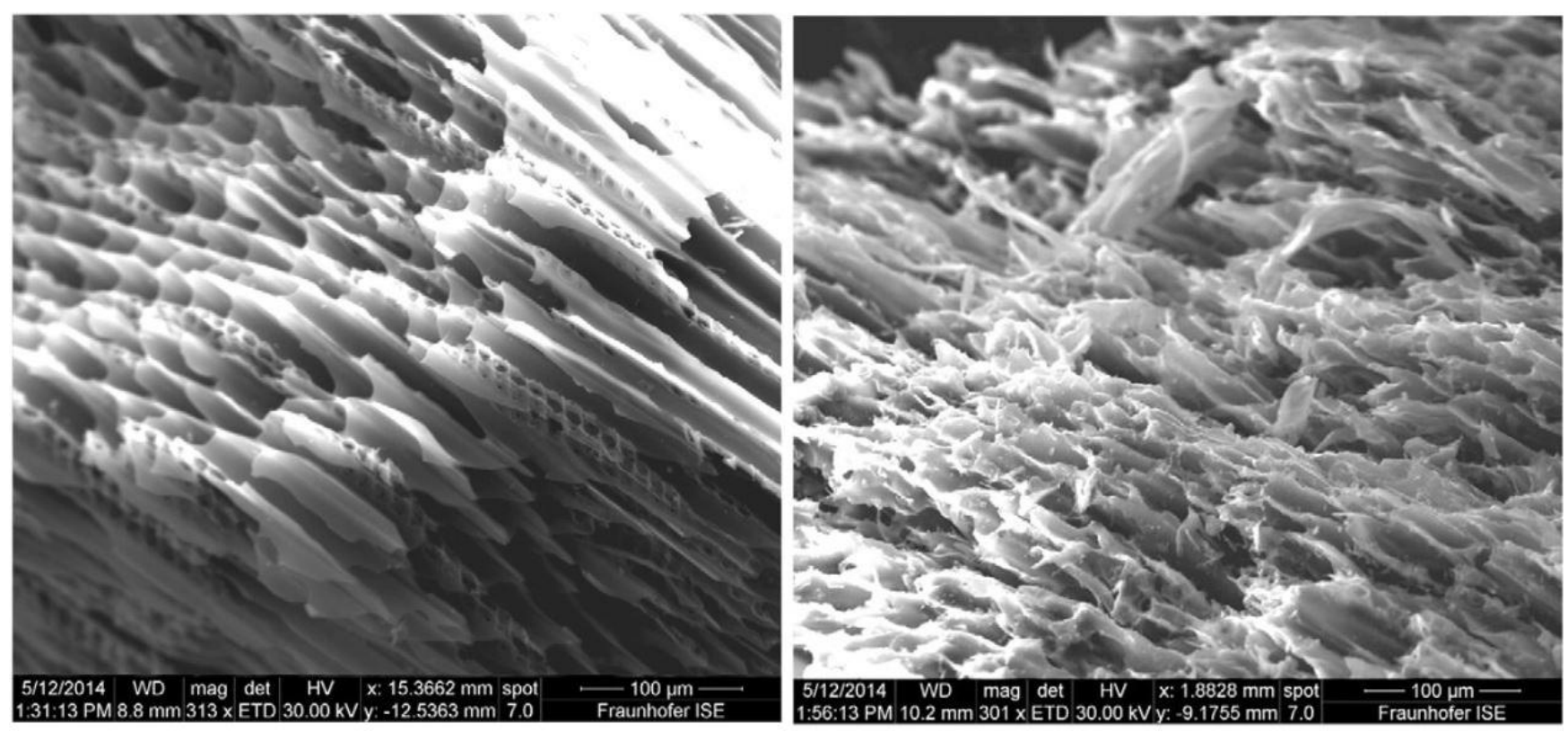

Figure 7: Structural changes in activated biochar after 5 hours of naphthalene exposure at $850^{\circ} \mathrm{C}$. The tracheids fracturing is due to cracking reactions, including carbon deposition. (Adapted from [60], pag 38. Copyright 2016 Elsevier)

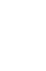

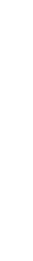
(1) (1) 


\begin{tabular}{|c|c|c|c|}
\hline Model tar & Tar class & Formula & Structure \\
\hline Methane & - & $\mathrm{CH}_{4}$ & \\
\hline Toluene & II & $\mathrm{C}_{6} \mathrm{H}_{5}-\mathrm{CH}_{3}$ & \\
\hline Phenol & II & $\mathrm{C}_{6} \mathrm{H}_{6} \mathrm{O}$ & \\
\hline Naphthalene & III & $\mathrm{C}_{10} \mathrm{H}_{8}$ & \\
\hline Phenanthrene & III & $\mathrm{C}_{14} \mathrm{H}_{10}$ & \\
\hline Anthracene & III & $\mathrm{C}_{14} \mathrm{H}_{10}$ & \\
\hline Pyrene & III & $\mathrm{C}_{16} \mathrm{H}_{10}$ & \\
\hline
\end{tabular}

Table 1: Common tar model compounds 



\begin{tabular}{|c|c|c|c|c|c|}
\hline Author & $\begin{array}{l}\text { Tested model } \\
\text { compounds }\end{array}$ & $\begin{array}{c}\text { Tested Char } \\
\text { (carbonization temperature) }\end{array}$ & $\begin{array}{c}\text { Char bed } \\
\text { temperature } \\
{\left[{ }^{\circ} \mathrm{C}\right]}\end{array}$ & $\begin{array}{c}\text { Char } \\
\text { particle } \\
\text { size } \\
{[\mu \mathrm{m}]}\end{array}$ & $\begin{array}{l}\text { Reaction } \\
\text { atmosphere } \\
\text { composition }\end{array}$ \\
\hline $\begin{array}{c}{[33]} \\
\text { Muradov et } \\
\text { al. }\end{array}$ & Methane & $\begin{array}{c}\text { Carbon black } \\
\text { Commercial AC } \\
\text { Various carbon materials (graphite, } \\
\text { glassy carbon, acetylene black) }\end{array}$ & 850 & n.r. & $\mathrm{CH}_{4}$ \\
\hline $\begin{array}{l}\text { [34] Moliner } \\
\text { et al. }\end{array}$ & Methane & $\begin{array}{l}\text { Commercial ACs } \\
\text { Coal char }\left(800^{\circ} \mathrm{C}\right)\end{array}$ & $850-950$ & $<100$ & $\mathrm{CH}_{4}$ \\
\hline $\begin{array}{l}\text { [35] Suelves } \\
\text { et al. }\end{array}$ & Methane & $\begin{array}{c}\text { Carbon black } \\
\text { Commercial AC }\end{array}$ & 900 & n.r. & $\mathrm{CH}_{4}$ \\
\hline $\begin{array}{l}\text { [36] Dufour } \\
\text { et al. }\end{array}$ & Methane & Pine wood char $\left(750^{\circ} \mathrm{C}\right)$ & 1000 & $200-400$ & $\begin{array}{c}\mathrm{N}_{2}, \mathrm{CH}_{4}, \text { mix of } \\
\mathrm{H}_{2} / \mathrm{CO} / \mathrm{CO}_{2} \\
\text { (artificial syngas) }\end{array}$ \\
\hline $\begin{array}{l}\text { [40] Dufour } \\
\text { et al. }\end{array}$ & Methane & $\begin{array}{c}\text { Pine wood char }\left(750^{\circ} \mathrm{C}\right) \\
\text { Demineralised pine wood } \operatorname{char}\left(750^{\circ} \mathrm{C}\right)\end{array}$ & 1000 & $200-400$ & $\mathrm{~N}_{2}, \mathrm{H}_{2} \mathrm{O}$ \\
\hline $\begin{array}{l}\text { [41] } \\
\text { Klinghoffer } \\
\text { et al. }\end{array}$ & $\begin{array}{l}\text { Methane } \\
\text { Propane }\end{array}$ & $\begin{array}{c}\text { Poplar char } \\
\left(\mathrm{CO}_{2} \text { and } \mathrm{H}_{2} \mathrm{O} \text { gasified at } 550,750 \text { and }\right. \\
\left.920^{\circ} \mathrm{C}\right)\end{array}$ & 20- 900 & $\begin{array}{c}\text { (Parent) } \\
1000-4000\end{array}$ & $\mathrm{~N}_{2}$ \\
\hline $\begin{array}{c}{[25]} \\
\text { Klinghoffer } \\
\text { et al. }\end{array}$ & Methane & $\begin{array}{c}\text { Poplar char } \\
\left(\mathrm{CO}_{2} \text { and } \mathrm{H}_{2} \mathrm{O} \text { gasified at } 550,750 \text { and }\right. \\
\left.920^{\circ} \mathrm{C}\right)\end{array}$ & $700-750-850$ & $\begin{array}{c}\text { (Parent) } \\
1000-4000\end{array}$ & $\mathrm{~N}_{2}$ \\
\hline
\end{tabular}

Table 2: Overview of experimental conditions for tests on alkanes decomposition 


\begin{tabular}{|c|c|c|c|c|c|}
\hline Author & $\begin{array}{l}\text { Tested model } \\
\text { compounds }\end{array}$ & $\begin{array}{c}\text { Tested Char } \\
\text { (carbonization temperature) }\end{array}$ & $\begin{array}{c}\text { Char bed } \\
\text { temperature } \\
{\left[{ }^{\circ} \mathrm{C}\right]}\end{array}$ & $\begin{array}{c}\text { Char } \\
\text { particle } \\
\text { size } \\
{[\mu \mathrm{m}]}\end{array}$ & $\begin{array}{l}\text { Reaction atmosphere } \\
\text { composition }\end{array}$ \\
\hline [17] Mastral et al. & $\begin{array}{l}\text { Phenanthrene } \\
\text { (1.5 ppm) }\end{array}$ & $\begin{array}{l}10 \text { carbonaceous materials } \\
\text { (various parent materials) }\end{array}$ & $125,150,175$ & $100-200$ & Helium \\
\hline [48] Mastral et al. & $\begin{array}{l}\text { Naphthalene } \\
\text { Phenanthrene } \\
\text { Pyrene } \\
(1.5 \mathrm{ppm})\end{array}$ & $\begin{array}{l}16 \text { carbonaceous materials } \\
\text { (various parent materials) }\end{array}$ & n.r. & $100-200$ & Helium \\
\hline [31] Mastral et al. & $\begin{array}{l}\text { Phenanthrene } \\
\text { (1.5 ppm) }\end{array}$ & $\begin{array}{l}16 \text { carbonaceous materials } \\
\text { (various parent materials) }\end{array}$ & 150 & $100-200$ & $\begin{array}{c}\text { Helium } \\
\text { Steam }(0-20 \%)\end{array}$ \\
\hline [16] Mastral et al. & $\begin{array}{c}\text { Naphthalene } \\
\text { Acenaphthene, } \\
\text { Fluorene, } \\
\text { Phenanthrene, } \\
\text { Anthracene, } \\
\text { Fluoranthene, } \\
\text { Pyrene }\end{array}$ & Coke from German Rhenish lignite & 150 & $100-200$ & Helium \\
\hline [49] Mastral et al & $\begin{array}{l}\text { Naphthalene } \\
\text { Fluorene, } \\
\text { Phenanthrene, } \\
\text { Fluoranthene, } \\
\text { Pyrene } \\
\end{array}$ & Coke from German Rhenish lignite & 150 & $100-200$ & Helium \\
\hline [50] García et al. & $\begin{array}{l}\text { Phenanthrene } \\
\text { (1.5 ppm) }\end{array}$ & $\begin{array}{l}\text { Commercial AC (with various degrees } \\
\text { of surface oxidation) }\end{array}$ & 150 & $100-200$ & Helium \\
\hline [15] Hu et al. & $\begin{array}{c}\text { Phenol } \\
\text { o-cresol } \\
\text { Naphthalene } \\
1- \\
\text { methylnaphthalene } \\
\end{array}$ & Commercial activated carbons & $150-250$ & $\begin{array}{l}1000 \\
2000 \\
4000\end{array}$ & $\mathrm{~N}_{2}$ \\
\hline $\begin{array}{l}\text { [51] Lillo-Ródenas } \\
\text { et al. }\end{array}$ & $\begin{array}{l}\text { Benzene } \\
\text { Toluene }\end{array}$ & $\begin{array}{c}\text { Commercial activated carbons } \\
\text { Steam activated char } \\
\text { Chemical activated chars }(\mathrm{NaOH} \text {, } \\
\mathrm{KOH})\end{array}$ & 25 & $\begin{array}{l}\text { Powder } \\
\text { Granular } \\
(1300- \\
1500) \\
\text { Pellets } \\
(2200) \\
\end{array}$ & Helium \\
\hline
\end{tabular}

Table 3: Overview of experimental conditions for adsorption of aromatics on char 


\begin{tabular}{|c|c|c|c|c|c|}
\hline Author & $\begin{array}{l}\text { Tested model } \\
\text { compounds }\end{array}$ & $\begin{array}{c}\text { Tested Char } \\
\text { (carbonization temperature) }\end{array}$ & $\begin{array}{c}\text { Char bed } \\
\text { temperature } \\
{\left[{ }^{\circ} \mathrm{C}\right]}\end{array}$ & $\begin{array}{c}\text { Char } \\
\text { particle } \\
\text { size } \\
{[\mu \mathrm{m}]}\end{array}$ & $\begin{array}{l}\text { Reaction } \\
\text { atmosphere } \\
\text { composition }\end{array}$ \\
\hline [52] Egsgaard et al. & $\begin{array}{c}\text { Benzene } \\
\text { Phenol } \\
\text { Naphthalene } \\
\text { Phenanthrene }\end{array}$ & Pine char $\left(800^{\circ} \mathrm{C}\right)$ & $600-800$ & $100-500$ & $\begin{array}{c}\mathrm{N}_{2} \\
\mathrm{H}_{2} \mathrm{O}\end{array}$ \\
\hline $\begin{array}{l}\text { [53] Abu El-Rub et } \\
\text { al. }\end{array}$ & $\begin{array}{l}\text { Phenol } \\
\text { Naphthalene }\end{array}$ & $\begin{array}{c}\text { Calcinated dolomite, Olivine } \\
\text { Fluid catalytic cracking } \\
\text { Nickel catalyst } \\
\text { Commercial biomass char } \\
\text { Pinewood char }\left(500^{\circ} \mathrm{C}\right) \\
\text { Pinewood ash }\left(600^{\circ} \mathrm{C}\right) \\
\end{array}$ & $700-900$ & $1400-1700$ & $\begin{array}{c}\mathrm{N}_{2}, \mathrm{CO}_{2} \\
\mathrm{H}_{2} \mathrm{O}\end{array}$ \\
\hline [37] Hosokai et al. & $\begin{array}{c}\text { Benzene } \\
\text { Phenol } \\
\text { Naphthalene } \\
\text { Phenanthrene } \\
\text { Pyrene } \\
\end{array}$ & Commercial char $\left(800^{\circ} \mathrm{C}\right)$ & $700-900$ & $1300-2400$ & $\begin{array}{c}\mathrm{N}_{2} \\
\mathrm{H}_{2} \mathrm{O} / \mathrm{N}_{2} \\
\mathrm{H}_{2} \mathrm{O} / \mathrm{H}_{2} / \mathrm{N}_{2}\end{array}$ \\
\hline $\begin{array}{l}\text { [38] Fuentes-Cano } \\
\text { et al. }\end{array}$ & $\begin{array}{l}\text { Toluene } \\
\text { Naphthalene }\end{array}$ & $\begin{array}{c}\text { Coconut char (commercial) } \\
\text { Coal char (commercial) } \\
\text { Dry sewage sludge char }\left(900^{\circ} \mathrm{C}\right)\end{array}$ & $750,850,950$ & $1000-2800$ & $\begin{array}{c}\mathrm{N}_{2} \\
\mathrm{H}_{2} / \mathrm{H}_{2} \mathrm{O}\end{array}$ \\
\hline [54] Nitsch et al. & Phenol & Beech wood char $\left(750^{\circ} \mathrm{C}\right)$ & 850 & $700-1000$ & $\begin{array}{c}\mathrm{N}_{2} \\
\mathrm{H}_{2} / \mathrm{H}_{2} \mathrm{O}\end{array}$ \\
\hline [55]Huang et al. & Toluene & $\begin{array}{c}\text { Sewage Sludge char }\left(900^{\circ} \mathrm{C}\right) \\
\text { Bottom ashes } \\
\text { Dolomite } \\
\mathrm{NiO} / \gamma-\mathrm{Al}_{2} \mathrm{O}_{3} \\
\end{array}$ & $750,850,950$ & $1000-1700$ & $\mathrm{~N}_{2}$ \\
\hline [56]Lu et al. & Toluene & Sewage Sludge char $\left(900^{\circ} \mathrm{C}\right)$ & $750,850,950$ & $1000-1700$ & $\begin{array}{c}\mathrm{N}_{2} \\
\mathrm{CO}_{2} / \mathrm{H}_{2} \mathrm{O} \\
\mathrm{CO} / \mathrm{H}_{2} / \mathrm{HCl}\end{array}$ \\
\hline [57] Bhandari et al. & Toluene & $\begin{array}{c}\text { Switchgrass char (downdraft gasifier) } \\
\text { Activated switchgrass char } \\
\text { Acidic surface activated char } \\
\end{array}$ & 700,800 & $150-600$ & $\begin{array}{c}\mathrm{N}_{2} \\
\text { Artificial syngas } \\
\left(\mathrm{CH}_{4} / \mathrm{H}_{2} / \mathrm{CO} / \mathrm{CO}_{2}\right) \\
\end{array}$ \\
\hline [58]Mani et al. & Toluene & Pine bark char $\left(950^{\circ} \mathrm{C}\right)$ & $600-900$ & $212-420$ & $\mathrm{~N}_{2} / \mathrm{H}_{2} \mathrm{O}$ \\
\hline [59] Korus et al. & Toluene & Coal-derived activated carbon & $650-850$ & $400-850$ & $\mathrm{~N}_{2}$ \\
\hline [39] Y. Zhang et al. & Naphthalene & $\begin{array}{c}\text { Rice straw char }\left(500^{\circ} \mathrm{C}\right) \\
\mathrm{Ni}\left(\mathrm{NO}_{3}\right)_{2} \text { loaded char } \\
\text { Water-washed char }\end{array}$ & $700-900$ & $\begin{array}{l}\text { (Parent) } \\
100-150\end{array}$ & $\begin{array}{c}\text { Argon } \\
\text { Artificial syngas } \\
\left(\mathrm{CH}_{4} / \mathrm{H}_{2} / \mathrm{CO} / \mathrm{CO}_{2}\right)\end{array}$ \\
\hline $\begin{array}{l}\text { [23] Di Gregorio et } \\
\text { al. }\end{array}$ & Naphthalene & Commercial ACs (three types) & $750-900$ & $\begin{array}{c}3000 \\
\text { (pellets) }\end{array}$ & $\mathrm{N}_{2}$ \\
\hline [60] Nestler at al. & Naphthalene & $\begin{array}{c}\text { Spruce char }\left(500^{\circ} \mathrm{C}, 800^{\circ} \mathrm{C}\right) \\
\mathrm{CO}_{2} \text {-activated spruce char } \\
\text { Commercial AC }\end{array}$ & 850,1050 & $500-2000$ & $\mathrm{~N}_{2}$ \\
\hline [61] Feng et al. & $\begin{array}{l}\text { Toluene, Phenol, } \\
\text { Naphthalene }\end{array}$ & $\begin{array}{c}\text { Rice husk char (RHC) } \\
\text { Acid washed RHC (H-form) } \\
\text { K-loaded RHC (K-form) } \\
\text { Ca-loaded RHC }\left(800^{\circ} \mathrm{C}\right) \\
\end{array}$ & 800 & $\begin{array}{l}900-1500 \\
\text { (parent) }\end{array}$ & $\mathrm{H}_{2} \mathrm{O} / \mathrm{CO}_{2}$ \\
\hline [62] Hervy et al. & Ethylbenzene & $\begin{array}{l}\text { Wood pallets/Food waste/ } \\
\text { Sludge char }\left(700^{\circ} \mathrm{C}\right)\end{array}$ & 400,650 & $500-1600$ & $\mathrm{~N}_{2}, \mathrm{CO}$ \\
\hline
\end{tabular}

Table 4: Experimental conditions overview of tar model compounds tests 
Table 5

\begin{tabular}{|c|c|c|c|c|c|c|}
\hline & $\mathbf{H}_{2}[\%]$ & $\mathbf{C H}_{4}$ & $\mathbf{C O}_{2}$ & $\mathbf{C O}$ & $\mathbf{H}_{2} \mathbf{O}$ & others \\
\hline [57]Bhandari et al. & 5.2 & 7.5 & 16.8 & 19.3 & - & $\mathrm{N}_{2}$ balance \\
\hline \multirow{2}{*}{ [56]Lu et al. } & & & 12.5 & & 15 & $\mathrm{~N}_{2} 72.5 \%$ \\
\cline { 2 - 7 } & 6 & & & 5 & 15 & $\mathrm{~N}_{2} 74 \%$ \\
\hline
\end{tabular}

Table 5: Artificial syngas compositions from Bhandari et al.[57] and Lu et al.[56] 


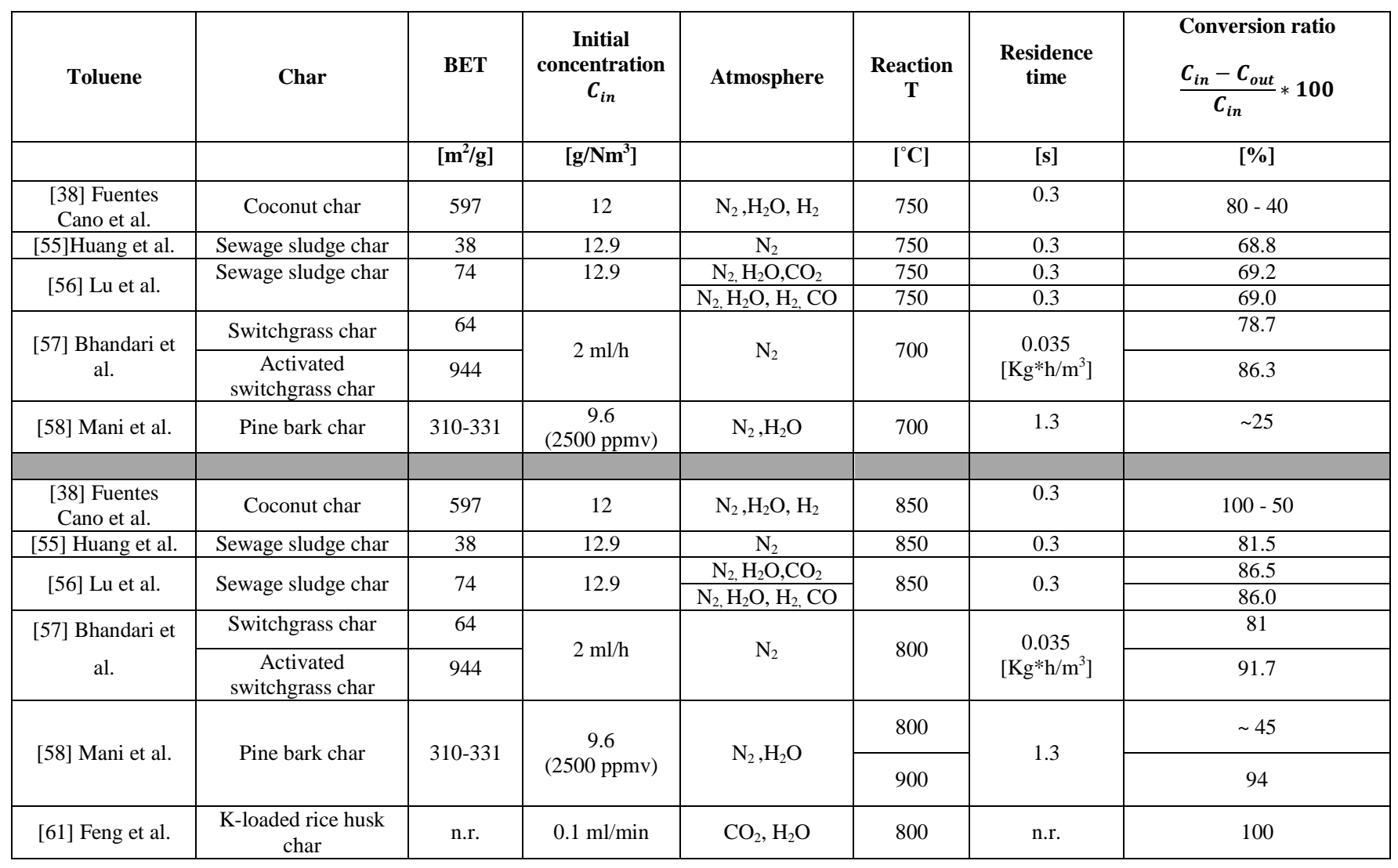

Table 6: Overview of conversion efficiencies for toluene (n.r. = not reported) 


\begin{tabular}{|c|c|c|c|c|c|c|c|}
\hline Naphthalene & Char & BET & $\begin{array}{c}\text { Initial } \\
\text { concentration } \\
C_{i n}\end{array}$ & Atmosphere & $\begin{array}{c}\text { Reaction } \\
\mathbf{T}\end{array}$ & $\begin{array}{l}\text { Residence } \\
\text { time }\end{array}$ & $\begin{array}{c}\text { Conversion ratio } \\
X=\frac{C_{\text {in }}-C_{\text {out }}}{C_{\text {in }}} * 100\end{array}$ \\
\hline & & {$\left[\mathrm{m}^{2} / \mathrm{g}\right]$} & {$\left[\mathrm{g} / \mathrm{Nm}^{3}\right]$} & & {$\left[{ }^{\circ} \mathbf{C}\right]$} & {$[\mathbf{s}]$} & {$[\%]$} \\
\hline $\begin{array}{l}\text { [37] Hosokai et } \\
\text { al. }\end{array}$ & Commercial char & 740 & 1.5 & $\mathrm{~N}_{2}, \mathrm{H}_{2} \mathrm{O}, \mathrm{H}_{2}$ & 700 & 0.2 & 73 \\
\hline $\begin{array}{l}\text { [38] Fuentes } \\
\text { Cano et al. }\end{array}$ & Coconut char & 597 & 8 & $\mathrm{~N}_{2}, \mathrm{H}_{2} \mathrm{O}, \mathrm{H}_{2}$ & 750 & 0.3 & $90-30(60 \mathrm{~min})$ \\
\hline $\begin{array}{l}\text { [39] Zhang et } \\
\text { al. }\end{array}$ & Rice straw char & 262 & 25.2 & $\mathrm{Ar}$ & 700 & $\begin{array}{c}20-30 \mathrm{~mm} \\
\text { bed height; } \\
12 \mathrm{~mL} / \mathrm{min} \\
\text { gas flow }\end{array}$ & 58 \\
\hline $\begin{array}{l}{[23] \mathrm{Di}} \\
\text { Gregorio et al. }\end{array}$ & Activated coal char & 740 & $50-176.7$ & $\mathrm{~N}_{2}$ & 750 & $\begin{array}{l}50 \mathrm{~mm} \text { bed } \\
\text { height; } \\
20 \mathrm{~mL} / \mathrm{min} \\
\text { gas flow }\end{array}$ & 42 \\
\hline $\begin{array}{l}\text { [53] El-Rub et } \\
\text { al. }\end{array}$ & $\begin{array}{l}\text { Commercial } \\
\text { biomass char }\end{array}$ & n.r. & 90 & $\mathrm{~N}_{2}, \mathrm{CO}_{2}, \mathrm{H}_{2} \mathrm{O}$ & 900 & 0.3 & 99.6 \\
\hline \multirow{2}{*}{$\begin{array}{l}\text { [37] Hosokai et } \\
\text { al. }\end{array}$} & \multirow{2}{*}{ Commercial char } & \multirow{2}{*}{740} & \multirow{2}{*}{3} & $\mathrm{~N}_{2}, \mathrm{H}_{2} \mathrm{O}$ & 850 & 0.2 & $>99.9$ \\
\hline & & & & $\mathrm{N}_{2}, \mathrm{H}_{2} \mathrm{O}, \mathrm{H}_{2}$ & 850 & 0.2 & 94 \\
\hline $\begin{array}{l}\text { [38] Fuentes } \\
\text { Cano et al. }\end{array}$ & Coconut char & 597 & 8 & $\mathrm{~N}_{2}, \mathrm{H}_{2} \mathrm{O}, \mathrm{H}_{2}$ & 850 & 0.3 & $100-60(60 \mathrm{~min})$ \\
\hline $\begin{array}{l}\text { [39] Zhang et } \\
\text { al. }\end{array}$ & Rice straw char & 262 & 25.2 & $\mathrm{Ar}$ & 800 & $\begin{array}{c}20-30 \mathrm{~mm} \\
\text { bed height; } \\
12 \mathrm{~mL} / \mathrm{min} \\
\text { gas flow }\end{array}$ & 77 \\
\hline $\begin{array}{c}{[23] \mathrm{Di}} \\
\text { Gregorio et al. }\end{array}$ & Activated coal char & 740 & $14.2-176.7$ & $\mathrm{~N}_{2}$ & 850 & $\begin{array}{l}50 \mathrm{~mm} \text { bed } \\
\text { height; } \\
20 \mathrm{~mL} / \mathrm{min} \\
\text { gas flow }\end{array}$ & 100 \\
\hline \multirow{2}{*}{$\begin{array}{l}\text { [60] Nestler et } \\
\text { al. }\end{array}$} & Activated wood char & 600 & 0.57 & $\mathrm{~N}_{2}$ & \multirow{2}{*}{850} & \multirow{2}{*}{0.19} & $93-15(120 \mathrm{~min})$ \\
\hline & Commercial AC & 950 & 0.57 & $\mathrm{~N}_{2}$ & & & 85-65 (120 min $)$ \\
\hline [61] Feng et al. & $\begin{array}{l}\text { K-loaded rice husk } \\
\text { char }\end{array}$ & n.r. & $0.1 \mathrm{ml} / \mathrm{min}$ & $\mathrm{CO}_{2}, \mathrm{H}_{2} \mathrm{O}$ & 800 & n.r. & 93.9 \\
\hline
\end{tabular}

Table 7: Overview of conversion efficiencies for naphthalene (n.r. $=$ not reported) 


\begin{tabular}{|c|c|c|c|}
\hline \multirow{2}{*}{ Model tar } & Catalyst & A & Ea \\
\cline { 3 - 4 } & & {$[\mathbf{K J} / \mathbf{m o l}]$} & 61 \\
\hline Naphthalene [53] & Commercial biomass char & $7.6 * 10^{4}$ & 72 \\
\hline Naphthalene [38] & Coconut biochar & $4 * 10^{5}$ & 75 \\
\hline Toluene [38] & Coconut biochar & $3.1 * 10^{5}$ & 90.6 \\
\hline Toluene [58] & Pine bark biochar & $2.6 * 10^{5}$ & 48.4 \\
\hline Toluene [68] & $18.7 \%$ Fe-loaded biochar & $5.4 * 10^{3}$ & \\
\hline
\end{tabular}

Table 8: Kinetics parameters for naphthalene and toluene decomposition over different chars 